Keywords: DWPF

SRAT

reductant

Retention: Permanent

\title{
Glycolic - Formic Acid Flowsheet Development
}

\author{
B.R. Pickenheim
}

M.E. Stone

J.D. Newell

September 28, 2010

Savannah River National Laboratory Savannah River Nuclear Solutions, LLC Aiken, SC 29808

Prepared for the U.S. Department of Energy under contract number DE-AC09-08SR22470.

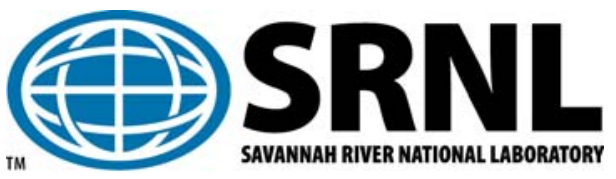


SRNL-STI-2010-00523

Revision 0

\section{DISCLAIMER}

This work was prepared under an agreement with and funded by the U.S. Government. Neither the U.S. Government or its employees, nor any of its contractors, subcontractors or their employees, makes any express or implied:

1. warranty or assumes any legal liability for the accuracy, completeness, or for the use or results of such use of any information, product, or process disclosed; or

2. representation that such use or results of such use would not infringe privately owned rights; or

3. endorsement or recommendation of any specifically identified commercial product, process, or service.

Any views and opinions of authors expressed in this work do not necessarily state or reflect those of the United States Government, or its contractors, or subcontractors.

\section{Printed in the United States of America \\ Prepared for \\ U.S. Department of Energy}




\section{REVIEWS AND APPROVALS}

AUTHORS:

B.R. Pickenheim, ERPS/Process Technology Programs

Date

M.E. Stone, ERPS/Process Technology Programs

Date

J.D. Newell, ERPS/Process Technology Programs

Date

TECHNICAL REVIEW:

D.P. Lambert, ERPS/Process Technology Programs

Date

APPROVAL:

C.C. Herman, Manager

Date

ERPS/Process Technology Programs

S.L. Marra, Manager

Date

Environmental \& Chemical Process Technology Research Programs

J.E. Occhipinti, Manager

Date

Waste Solidification Engineering 
SRNL-STI-2010-00523

Revision 0

\section{EXECUTIVE SUMMARY}

Flowsheet testing was performed to further develop the nitric/glycolic/formic acid flowsheet as an alternative to the nitric/formic flowsheet currently being processed at the DWPF. This new flowsheet has shown that mercury can be removed in the Sludge Receipt and Adjustment Tank (SRAT) with minimal hydrogen generation. All other processing objectives were also met, including greatly reducing the Slurry Mix Evaporator (SME) product yield stress as compared to the baseline nitric/formic flowsheet. Eight runs were performed in total, including the baseline run.

The baseline nitric/formic flowsheet run was extremely difficult to process under existing DWPF acceptance criteria with this simulant at the HM levels of noble metals. While nitrite was destroyed and mercury was removed to near the DWPF limit, the rheology of the SRAT and SME products were well above design basis and hydrogen generation far exceeded the DWPF limit. In addition, mixing during the SME cycle was very poor. In this sense, the nitric/glycolic/formic acid flowsheet represents a significant upgrade over the current flowsheet. In the nitric/glycolic/formic flowsheet runs, mercury was successfully removed with almost no hydrogen generation and the SRAT and SME products yield stresses were within process limits or previously processed ranges.

It is recommended that DWPF continue to support development of the nitric/glycolic/formic flowsheet. Although experience is limited at this time, this flowsheet meets or outperforms the current flowsheet in many regards, including off-gas generation, mercury removal, product rheology and general ease of processing. Additional flowsheet testing will allow for a more thorough understanding of the chemistry and effectiveness of the flowsheet over a range of sludge compositions and formic/glycolic ratios. This testing will also show whether the REDOX and metal solubility concerns with this change in the flowsheet can be addressed by just adjusting the volumes of glycolic acid added.

The outstanding issues regarding the glycolic/formic flowsheet include increasing understanding of the impact on glass REDOX control and increased metal solubility, particularly iron, during processing. Additionally, evaluations of the utility of the flowsheet over varying sludge compositions should be completed to ensure flowsheet robustness. Work has already been initiated to further understand the REDOX and iron solubility areas. 


\section{TABLE OF CONTENTS}

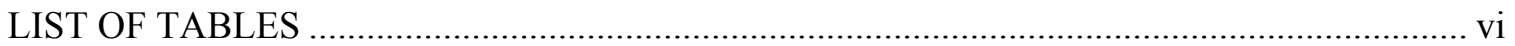

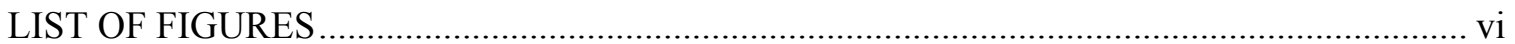

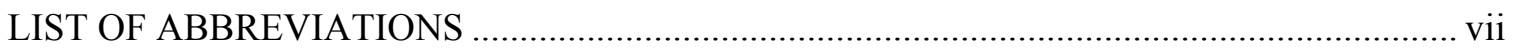

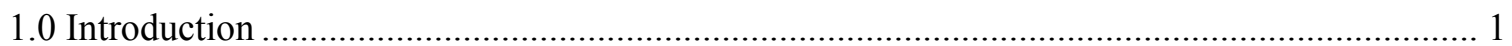

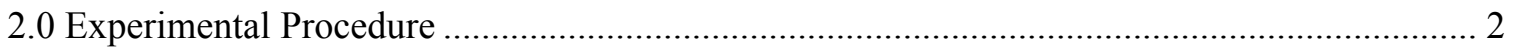

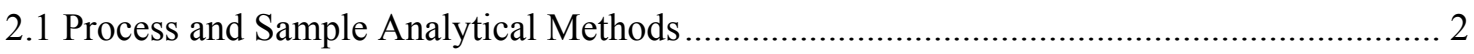

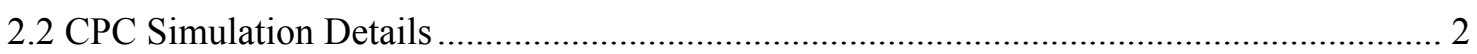

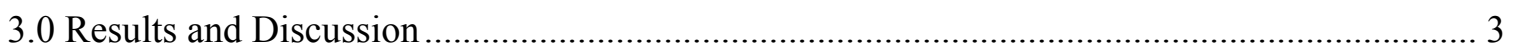

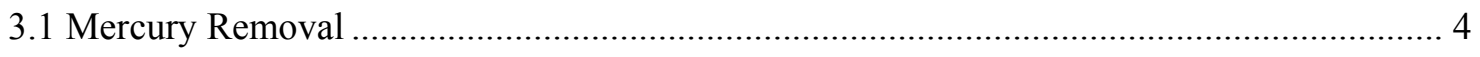

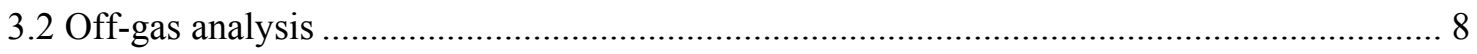

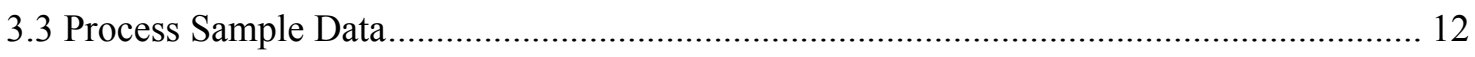

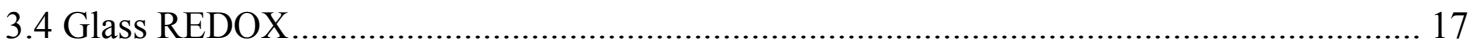

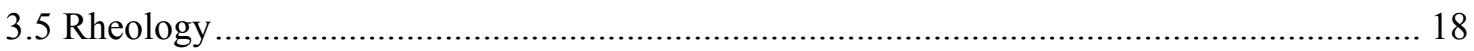

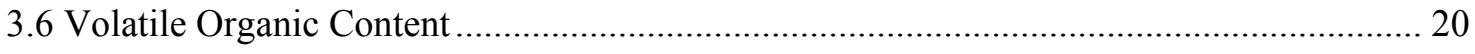

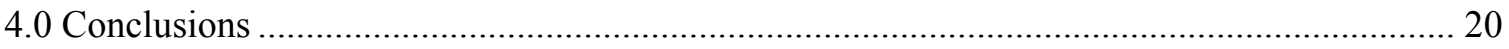

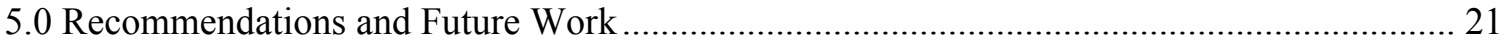

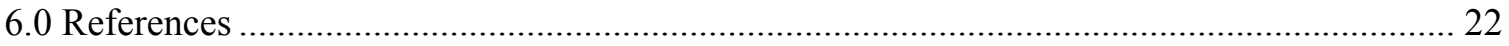

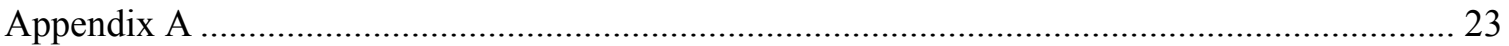




\section{LIST OF TABLES}

Table 1-1. Mercury and noble metal concentrations (dried solids basis) ..................................... 1

Table 2-1. CPC Simulation Process Assumptions........................................................................ 3

Table 3-1. Comparison of SRAT and SME Product Hg results ................................................ 6

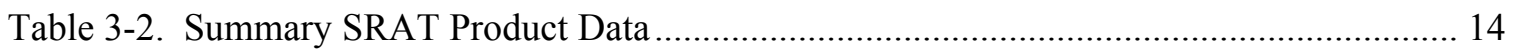

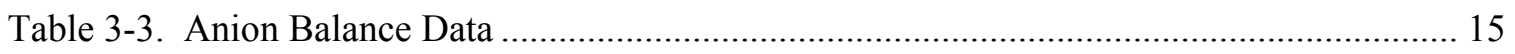

Table 3-4. SRAT Product Supernate \% of Element Dissolved ................................................... 16

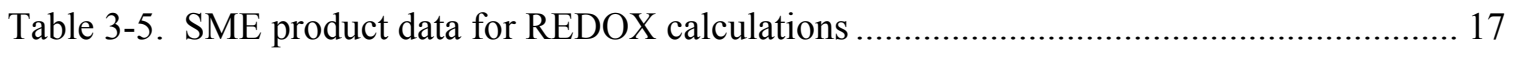

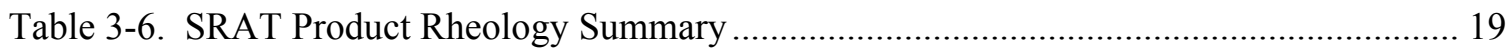

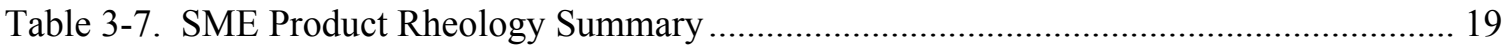

\section{LIST OF FIGURES}

Figure 1. Mercury concentration with time in baseline SRAT cycles........................................ 5

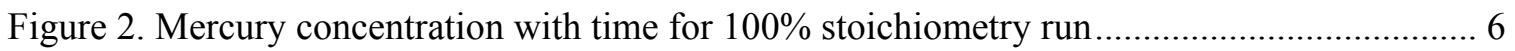

Figure 3. Mercury collection in SRAT condenser drain tube................................................... 7

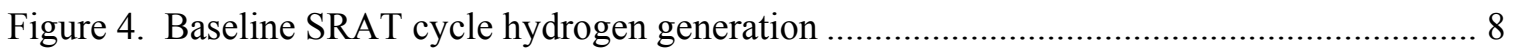

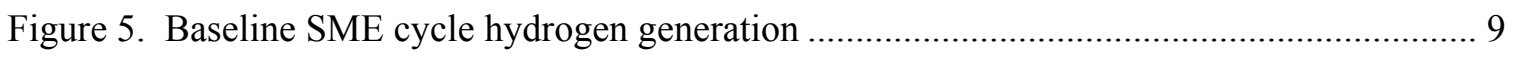

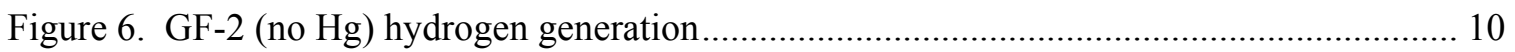

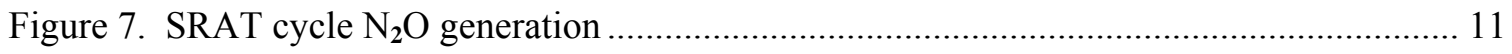

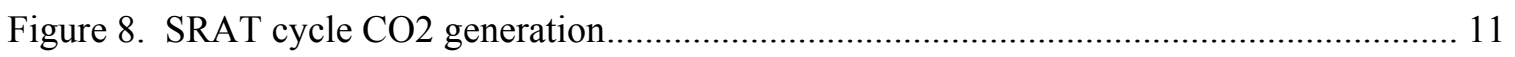

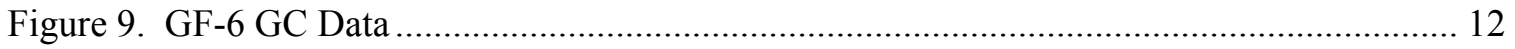

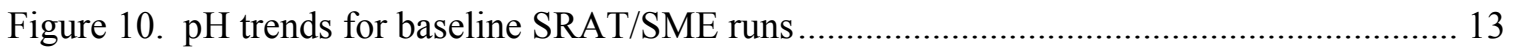

Figure 11. Iron solubility as a function of acid stoichiometry.............................................. 16

Figure 12. Measured REDOX dependence on acid stoichiometry ........................................... 18

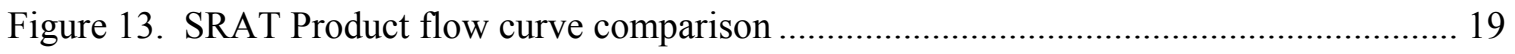




\section{LIST OF ABBREVIATIONS}

$\begin{array}{ll}\text { AD } & \text { Analytical Development } \\ \text { ARP } & \text { Actinide Removal Process } \\ \text { CPC } & \text { Chemical Process Cell } \\ \text { DWPF } & \text { Defense Waste Processing Facility } \\ \text { FAVC } & \text { Formic Acid Vent Condenser } \\ \text { MCU } & \text { Modular Caustic Side Solvent Extraction Unit } \\ \text { MWWT } & \text { Mercury Water Wash Tank } \\ \text { PSAL } & \text { Process Science Analytical Laboratory } \\ \text { REDOX } & \text { Reduction/Oxidation } \\ \text { SME } & \text { Slurry Mix Evaporator } \\ \text { SRAT } & \text { Sludge Receipt and Adjustment Tank } \\ \text { SRNL } & \text { Savannah River National Laboratory } \\ \text { SRR } & \text { Savannah River Remediation } \\ \text { TT\&QAP } & \text { Task Technical and Quality Assurance Plan } \\ \text { TTR } & \text { Technical Task Request }\end{array}$




\subsection{Introduction}

Savannah River Remediation (SRR) is evaluating changes to its current Defense Waste Processing Facility (DWPF) flowsheet to improve processing cycle times that will enable the process to support higher canister production while maximizing waste loading upon installation of the bubblers into the melter. Due to the significant maintenance required for the DWPF Gas Chromatographs (GC) and the potential for production of flammable quantities of hydrogen, reducing the amount of formic acid used in the Chemical Process Cell (CPC) is one of the options being considered. Earlier work at Savannah River National Laboratory has shown that replacing formic acid in the existing nitric/formic acid flowsheet with an 80:20 molar blend of glycolic and formic acids has the potential to remove mercury in the SRAT without any significant catalytic hydrogen generation. ${ }^{1}$

The objective of the testing detailed in this document is to further define the glycolic-formic acid flowsheet as requested by DWPF. ${ }^{2}$ This work was performed under the guidance of a Task Technical and Quality Assurance Plan (TT\&QAP). ${ }^{3}$

The sludge simulant required to complete this testing was procured from an off-site vendor. This simulant is being used to support all of the alternative flowsheet testing for the downselect process. The details regarding the simulant preparation and analysis have been documented separately. ${ }^{4}$ The simulant was based on Sludge Batch 6 with HM basis noble metal concentrations.

Table 1-1. Mercury and noble metal concentrations (wt\% dried solids basis)

\begin{tabular}{|c|c|}
\hline Element & $\begin{array}{c}\text { HM } \\
\text { Re-revised }\end{array}$ \\
\hline $\mathrm{Hg}$ & 3.263 \\
\hline $\mathrm{Ag}$ & 0.014 \\
\hline $\mathrm{Pd}$ & 0.079 \\
\hline $\mathrm{Rh}$ & 0.038 \\
\hline $\mathrm{Ru}$ & 0.217 \\
\hline
\end{tabular}

A total of eight CPC simulations including SRAT and SME cycles were performed. The first four tests were a baseline nitric-formic flowsheet, a baseline nitric-glycolic-formic flowsheet, a run without mercury and a run with Actinide Removal Process (ARP) and Modular Caustic Side Solvent Extraction (MCU) streams added. The second set of simulations included tests at varying acid stoichiometries to define the acid processing window and one test without any formic acid (nitric/glycolic acid only). No SME cycle was performed on the glycolic acid only flowsheet simulation.

Total boiling time in the SRAT cycles was calculated to remove mercury to $0.60 \mathrm{wt} \%$ in the total solids at a stripping rate of $750 \mathrm{lb}$ steam/lb Hg at the scaled maximum DWPF design rate of 5000 $\mathrm{lb} / \mathrm{hr}$ steam. Process samples were taken during the runs to monitor mercury concentration with time. Off-gas data were collected to monitor hydrogen as well as $\mathrm{CO}_{2}$ and $\mathrm{N}_{2} \mathrm{O}$ generation.

The amount of acid used in each simulation was calculated using the Koopman minimum acid equation. ${ }^{5}$ A stoichiometric factor of $125 \%$ was used for the baseline runs and factors varying from $100 \%$ to $200 \%$ were used for the acid window testing. The Hsu equivalents for these runs 
are $135 \%$ stoichiometry for the baseline and $108 \%$ to $215 \%$ for the acid window runs. REDOX was targeted at $0.2 \mathrm{Fe}^{+2} / \Sigma \mathrm{Fe}$ using a modified REDOX equation with a term for glycolate ion included.

\subsection{Experimental Procedure}

\subsection{Process and Sample Analytical Methods}

An automated data acquisition system was used to collect run data on a computer. The data collected includes SRAT slurry temperature, slurry $\mathrm{pH}$, cooling water temperatures for the SRAT condenser and Formic Acid Vent Condenser (FAVC), SRAT mixer speed, air and helium purge rates, and raw gas chromatographs.

Agilent 3000 Series GC's were used on all simulations to measure the offgas composition. The GCs were baked out and calibrated with standard calibration gas between runs. Calibration was verified following the completion of the SME cycles.

Process samples were analyzed by various methods. Slurry and supernate elemental compositions were measured by inductively coupled plasma-atomic emission spectroscopy (ICPAES) at the Process Science Analytical Laboratory (PSAL). Soluble anion concentrations were measured by Ion Chromatography (IC). Mercury concentration was measured by ICP-AES. Ammonium ion concentration on selected samples was measured by cation chromatography by SRNL Analytical Development (AD). Slurry and supernate densities were measured using an Anton-Parr instrument at PSAL. Reduction-Oxidation (REDOX) of glasses made from SME product slurries was measured by PSAL. Dewater and condensate samples were submitted to AD for volatile/semi-volatile organics analysis (VOA/SVOA).

\subsection{CPC Simulation Details}

A standard 4-L SRAT/SME apparatus with an ammonia scrubber was used for these simulations. The scrubber solution consisted of $749 \mathrm{~g}$ of de-ionized water and $1 \mathrm{~g}$ of $50 \mathrm{wt} \%$ nitric acid. The solution was recirculated through the column by a MasterFlex pump at $300 \mathrm{~mL} / \mathrm{min}$ through a spray nozzle at the top of the packed section. Glass rings were used as packing and did not significantly add to the back pressure on the SRAT vessel as has been seen in earlier tests with different packing.

Standard SRAT acid calculations were performed with a few modifications. The Koopman minimum acid equation was used with a $125 \%$ stoichiometric factor for the first set of tests. The acid mix was partitioned between nitric and the formic/glycolic blend by utilizing the latest REDOX equation ${ }^{6}$ with a term added for glycolate. A coefficient of 6 was used on the glycolate term based on electron equivalence. The REDOX target for these runs was 0.2.

$$
\begin{gathered}
\mathrm{REDOX}=0.2358+0.1999 *\left(\left(2 * \mathrm{C}_{\text {formate }}+4 * \mathrm{C}_{\text {oxalate }}+4 * \mathrm{C}_{\text {Carbon }}+6 * \mathrm{C}_{\text {glycolate }}-5 *\left(\mathrm{C}_{\text {Nitrate }}+\mathrm{C}_{\text {Nitrite }}\right)-\right.\right. \\
\left.\left.5 * \mathrm{C}_{\mathrm{Mn}}\right)\right) *(45 / \mathrm{TS})
\end{gathered}
$$

Where $\mathrm{C}=$ species concentration, $\mathrm{g}$-mole $/ \mathrm{kg}$ melter feed, $\mathrm{TS}=$ total solids in melter feed in wt $\%$, and REDOX is a molar ratio of $\mathrm{Fe}^{+2} / \Sigma \mathrm{Fe}$ 
Process assumptions were made to predict SME product anion concentrations. In addition to the standard assumptions needed for formate loss and nitrite to nitrate conversion, a factor was added to the acid calculation for glycolate loss. Process assumptions for the stoichiometric window testing were adjusted based on results from the first set of simulations. The following table identifies each run and its corresponding assumptions.

Table 2-1. CPC Simulation Process Assumptions

\begin{tabular}{|c|c|c|c|c|c|c|}
\hline Run ID & $\begin{array}{c}\text { Flowsheet } \\
\text { Description }\end{array}$ & $\begin{array}{c}\text { Nitrite- } \\
\text { Nitrate } \\
\text { Conversion }\end{array}$ & $\begin{array}{c}\text { Formate } \\
\text { Loss }\end{array}$ & $\begin{array}{c}\text { Glycolate } \\
\text { Loss }\end{array}$ & $\begin{array}{c}\text { Stoichiometric } \\
\text { Factor }\end{array}$ & $\begin{array}{c}\text { Acid } \\
\text { Added } \\
\text { (mol/L) }\end{array}$ \\
\hline GF-1 & $\begin{array}{c}\text { nitric/formic } \\
\text { baseline }\end{array}$ & $0 \%$ & $20 \%$ & N/A & $125 \%$ & 1.81 \\
\hline GF-2 & $\begin{array}{c}\text { nitric/glycolic/formic } \\
\text { no Hg }\end{array}$ & $0 \%$ & $20 \%$ & $20 \%$ & $125 \%$ & 1.78 \\
\hline GF-3 & $\begin{array}{c}\text { nitric/glycolic/formic } \\
\text { baseline }\end{array}$ & $0 \%$ & $20 \%$ & $20 \%$ & $125 \%$ & 1.81 \\
\hline GF-4 & $\begin{array}{c}\text { nitric/glycolic/formic } \\
\text { w/ ARP\&MCU }\end{array}$ & $0 \%$ & $20 \%$ & $20 \%$ & $125 \%$ & 2.09 \\
\hline GF-5 & nitric/glycolic/formic & $0 \%$ & $100 \%$ & $10 \%$ & $150 \%$ & 2.18 \\
\hline GF-6 & nitric/glycolic/formic & $0 \%$ & $100 \%$ & $10 \%$ & $100 \%$ & 1.45 \\
\hline GF-7 & nitric/glycolic/formic & $0 \%$ & $100 \%$ & $10 \%$ & $200 \%$ & 2.90 \\
\hline GF-8 & nitric/glycolic & $0 \%$ & N/A & $10 \%$ & $125 \%$ & 1.81 \\
\hline
\end{tabular}

DWPF design basis processing conditions were scaled down and used for most processing parameters including: SRAT/SME air purges, antifoam addition strategy, acid addition rates, and boil-up rate. No canister decontamination water additions were simulated. SRAT product total dried solids were targeted at $25 \mathrm{wt} . \%$ for the baseline run. Final SME total dried solids were targeted at $45 \%$ at $36 \%$ waste loading.

The SRAT product solids targets were adjusted for the glycolic/formic flowsheet runs because of the mass of the glycolate ion. Because its molar mass is about $2 / 3$ greater than formic, adding glycolic acid contributes an appreciable amount to SRAT product soluble (and thus total) solids. The SRAT product total dried solids targets were adjusted to $\sim 23 \%$ to match the amount of water in the SRAT product slurries. No adjustments were made to the SME cycle solids targets.

\subsection{Results and Discussion}

Typical SRAT/SME simulation analytical data will be presented in the following sections and Appendix A as necessary. While the focus of the study was on proving the glycolic/formic flowsheet could meet all current CPC processing objectives, most notably effective removal of mercury in the SRAT while simultaneously reducing hydrogen generation, a few issues arose during testing that merit additional discussion, those being REDOX control and iron solubility.

The focus of the data presented here will be comparison between the two baseline flowsheet cases, GF-1 and GF-3. These are the only runs performed under the same conditions with both flowsheets and therefore the only direct point of comparison. Data for GF-6, the 100\% stoichiometry nitric/glycolic/formic run, will also be presented because it appears that running at lower acid stoichiometry is more appropriate for the new flowsheet. Most of the data for the other tests will be placed in the appendix as the conclusions that are able to be drawn from those runs are limited. 
One observation that could be made for all of the simulations is that maintaining a well-mixed vessel was very challenging with this particular sludge feed and was independent of the flowsheet testing objective. The sludge prepared at Harrell Industries measured 31.5 Pa yield stress. With a typical 4-L SRAT vessel, air entrainment becomes a serious concern during periods of significant off-gas generation, that is, from early in acid addition through the entire period of $\mathrm{NO}_{\mathrm{x}}$ generation. A pocket of gas was found to build up around the agitator blades which prevented the bulk slurry from mixing. The agitator motor was stopped to allow the trapped gas to escape, followed by restarting the mixer. This method was effective for getting through acid addition without stopping acid flow, however, the mixer would need to be stopped and restarted at least once a minute. It is important to note that trapped air in the slurry caused by the unusually high yield stress is not the same as foaming in a classical sense. The trapped air caused an increase in slurry level, but no foam lamella was observed. Antifoam was added during one of the runs, but no decrease in slurry level was noted as a result of the addition. Again, this was common to all of the simulations with this simulant, not just the baseline run.

Another overall observation for these runs is that other than in the ARP/MCU test, foaminess was not really a concern. The ARP/MCU run foamed extensively during ARP addition while caustic boiling and antifoam was added as necessary. In the past, foaming during caustic boiling has not been an issue with simulants, though it is known to be a problem with real waste.

\subsection{Mercury Removal}

One of the most important questions to resolve concerning the glycolic/formic flowsheet is whether mercury could be effectively reduced and steam stripped in the SRAT cycle. The starting sludge was trimmed to $3.263 \mathrm{wt} \% \mathrm{Hg}$ in the total solids. This required a theoretical boiling time of nearly 36.5 hours to remove mercury to less than $0.60 \mathrm{wt} \%$ in the SRAT product total solids using lab-scaled DWPF design basis boil-up rates.

Samples were taken periodically throughout the runs for mercury analysis. The chart below shows the concentration of mercury in the slurry as a function of time for the two baseline flowsheet cases, GF-1 (nitric/formic) and GF-3 (nitric/glycolic/formic). 


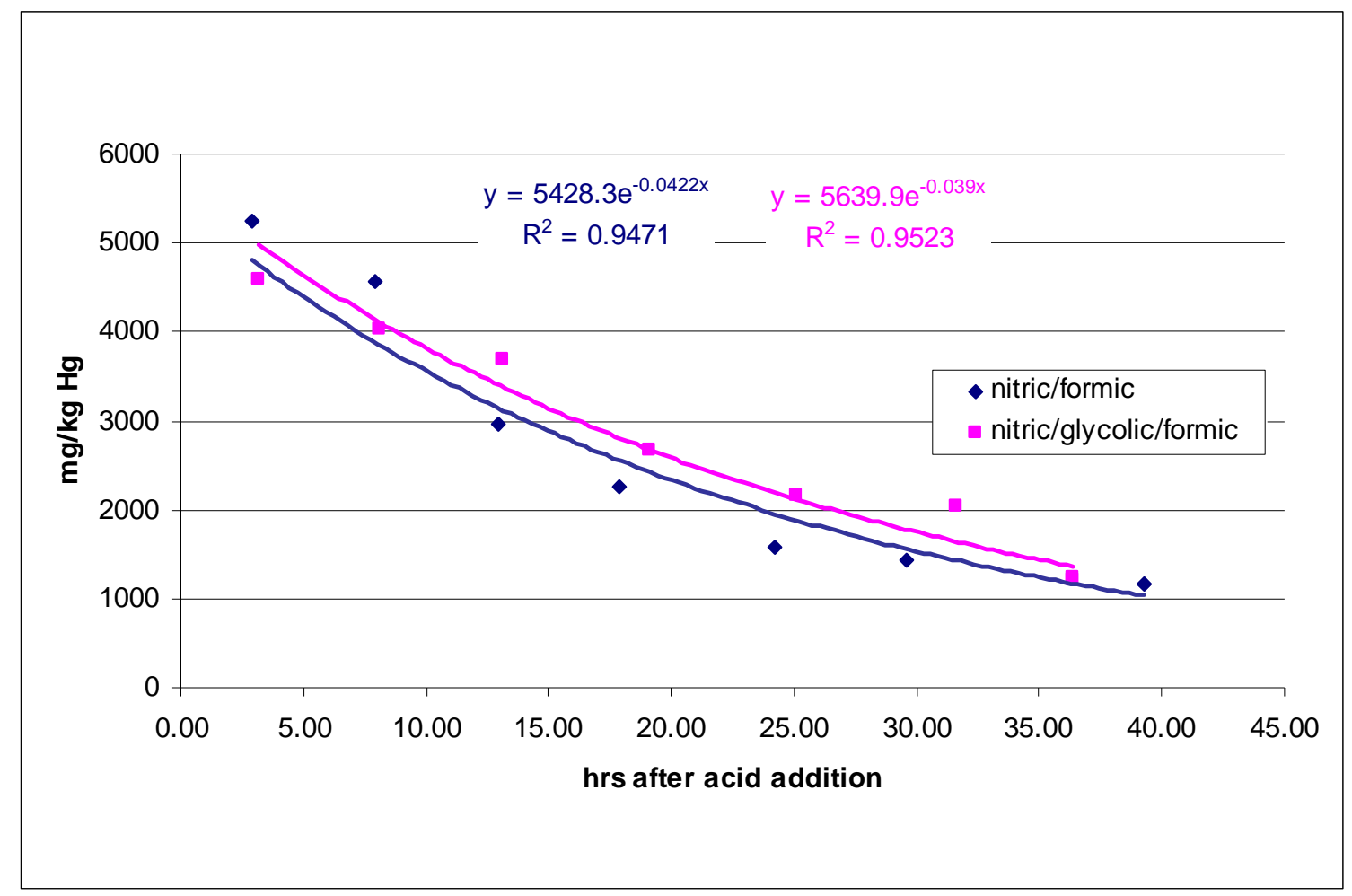

Figure 1. Mercury concentration with time in baseline SRAT cycles

This plot shows actual sample data along with a calculated exponential trend line for the two baseline flowsheets. The rate of mercury removal appears to be nearly identical for both flowsheets. On a total solids basis, the SRAT product concentration in the glycolic/formic flowsheet was $0.56 \mathrm{wt} \%$ while the SRAT product for the nitric/formic flowsheet measured 0.66 $\mathrm{wt} \%$. The next plot shows the mercury removal rate for the $100 \%$ stoichiometry run, GF- 6 . The rate of removal in this run also matches well with the two baseline cases. The final SRAT product mercury concentration was slightly above the limit in this run, $0.61 \mathrm{wt} \%$ in the total solids. 


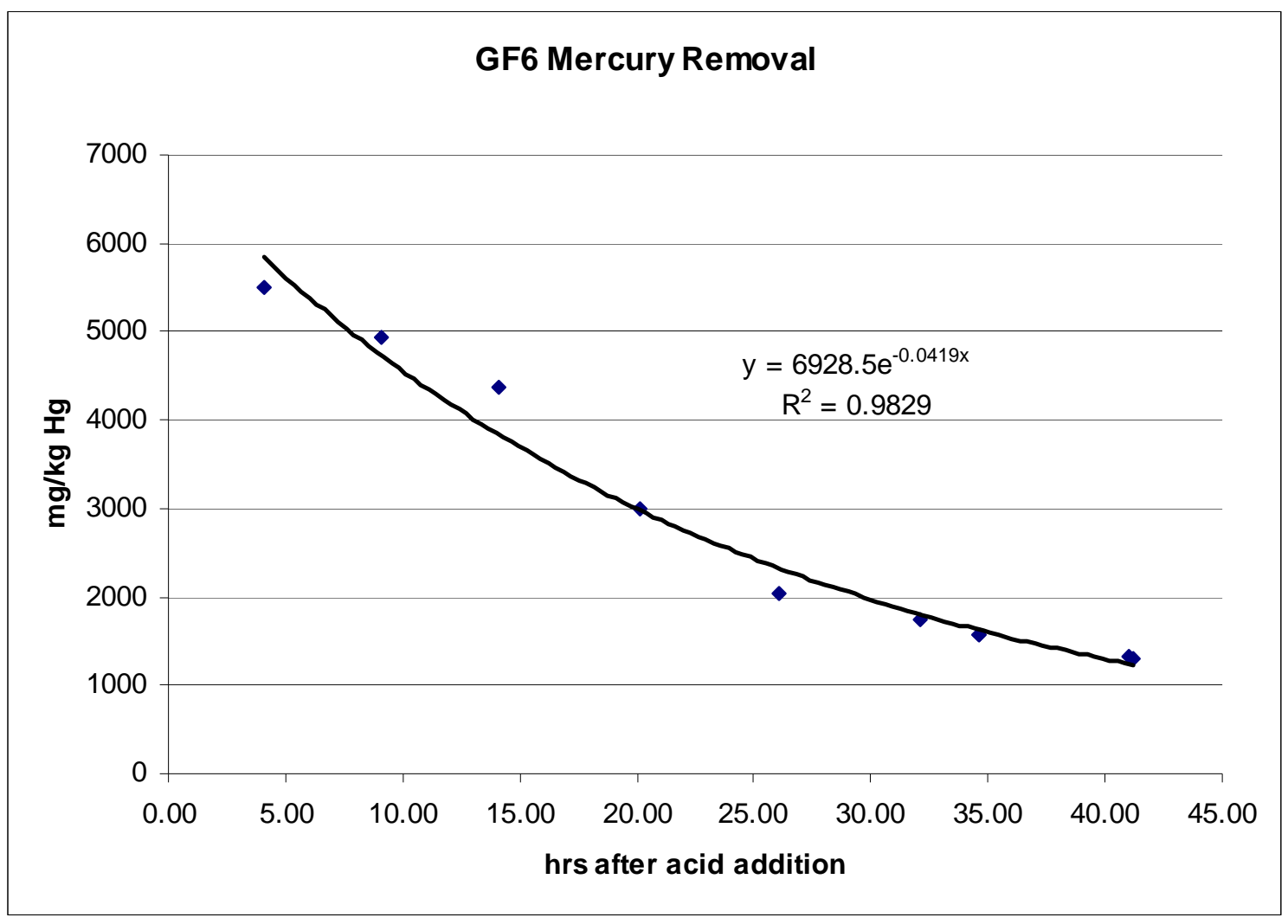

Figure 2. Mercury concentration with time for $100 \%$ stoichiometry run

The table below shows the SRAT and SME product mercury results for all of the runs in this series.

Table 3-1. Comparison of SRAT and SME Product Hg results

\begin{tabular}{||c|c|c|c||}
\hline Run & $\begin{array}{c}\text { Acid } \\
\text { Stoichiometry }\end{array}$ & $\begin{array}{c}\text { SRAT } \\
\text { Product Hg } \\
\text { (wt\% TS) }\end{array}$ & $\begin{array}{c}\text { SME } \\
\text { Product Hg } \\
\text { (wt\% TS) }\end{array}$ \\
\hline GF-1 & 125 & 0.66 & 0.29 \\
\hline GF-3 & 125 & 0.56 & 0.25 \\
\hline GF-4 & 125 & 0.97 & 0.39 \\
\hline GF-5 & 150 & 0.41 & 0.15 \\
\hline GF-6 & 100 & 0.61 & 0.25 \\
\hline GF-7 & 200 & 0.31 & 0.37 \\
\hline GF-8 & 125 & 0.39 & no SME \\
\hline
\end{tabular}

All of the runs with the exception of the ARP/MCU run (GF-4) had SRAT product mercury results near or below the limit of $0.60 \mathrm{wt} \%$ in the total solids. This run could be an outlier or the trim addition of mercury after caustic boiling may somehow affect the mercury removal rate. Additional testing with ARP/MCU would need to be done before potential implementation and this can be further addressed at that time. It is of particular interest that mercury was successfully removed in GF-8, a run with no formic acid. Glycolic acid did not show the ability to reduce mercury in earlier supernatant only screening studies ${ }^{1}$, which is why testing has focused on using 
the formic/glycolic blend. It is proposed that glycolic acid $\left(\mathrm{C}_{2} \mathrm{H}_{4} \mathrm{O}_{3}\right)$ is reacting with nitrite (or other species, e.g. $\left.\mathrm{MnO}_{2}\right)$ to form glyoxylic acid $\left(\mathrm{C}_{2} \mathrm{H}_{2} \mathrm{O}_{3}\right)$. The aldehyde form of glyoxylic acid then reacts with mercury oxide to form elemental mercury. The final form of the glycolic acid after these reactions is oxalic acid. This result potentially opens the door to completely removing formic acid from the flowsheet.

During the SRAT/SME process, mercury was collected in the Mercury Water Wash Tank (MWWT). The mercury tended not to coalesce into a single liquid phase, but instead come over as small beads. These beads would stick to the sides of the SRAT condenser drain tube rather than flowing to the sump in the MWWT. The mercury was dull in color. The sticking behavior qualitatively increased with increasing acid stoichiometry. The overall behavior of the mercury seemed to be consistent with previous observations of high acid runs in SB6 flowsheet studies. ${ }^{7}$ One possibility is that the antifoam degradation is increased in higher acid runs (lower $\mathrm{pH}$ ) and those degradation products form compounds with mercury. Analysis of the mercury collected during the runs is pending. The photo below was taken during the $200 \%$ acid stoichiometry run.

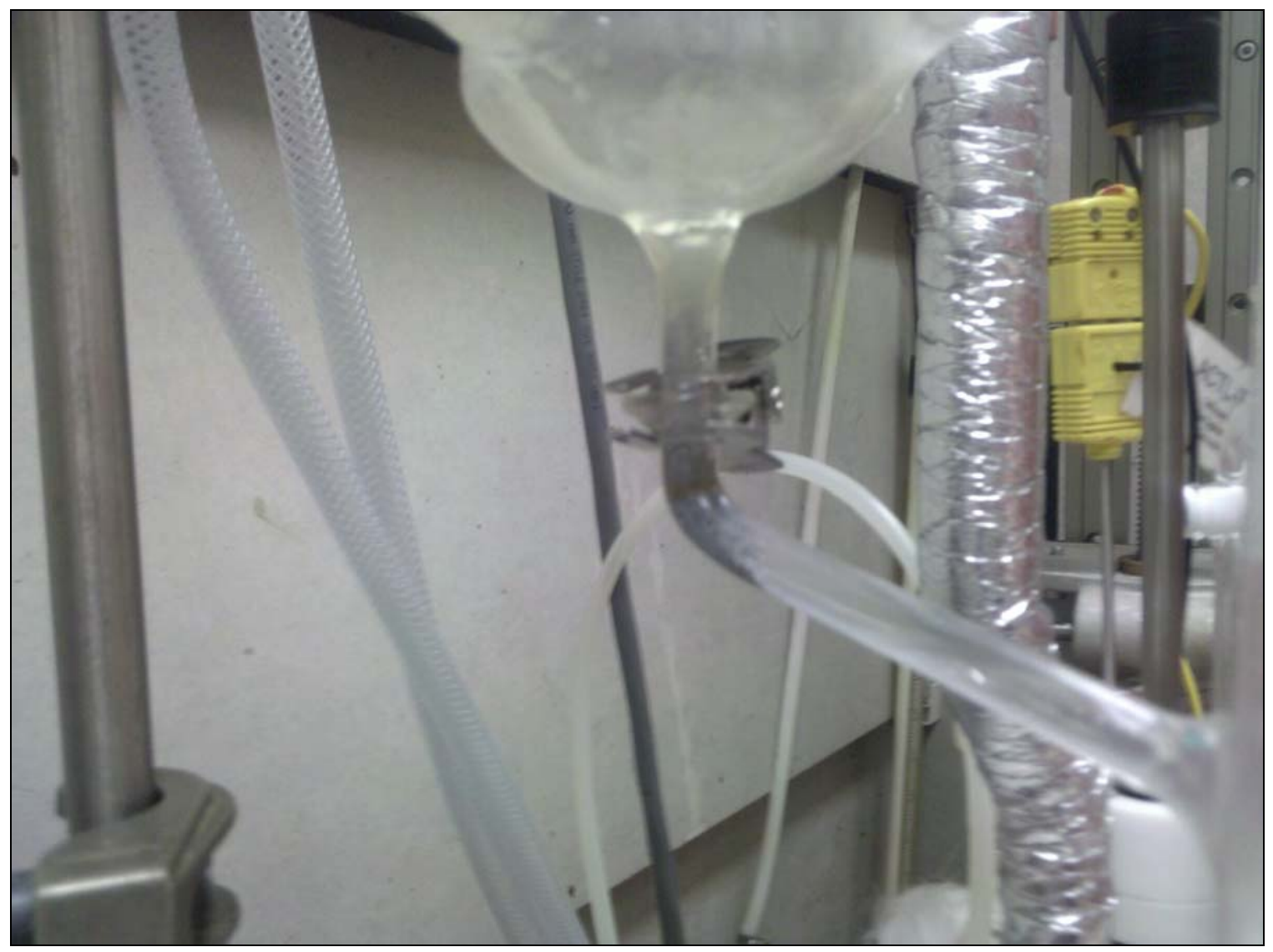

Figure 3. Mercury collection in SRAT condenser drain tube

All of the mercury removed and collected during these runs was retained for potential future analysis. Mercury stripping efficiency appears similar for the other runs. Plots of mercury concentration with time for all runs are included in Appendix A. 


\subsection{Off-gas analysis}

In addition to mercury removal, the other main objective of this flowsheet testing was to show that hydrogen generation could be mitigated or eliminated by the use of the glycolic/formic flowsheet. In the six simulations with the glycolic/formic flowsheet and mercury, hydrogen concentration in the off-gas never exceeded 0.03 volume percent in the SRAT cycle. When formic acid was added with the frit in the SME cycle, hydrogen generation on the order of 0.2 volume percent was noted in the $200 \%$ stoichiometry case, GF- 7 . This can be compared to the baseline nitric/formic flowsheet run where hydrogen concentration in the SRAT exceeded the DWPF design basis limit of $0.65 \mathrm{lbs} / \mathrm{hr}$ ( $>2$ volume percent). The chart below compares SRAT cycle hydrogen in the two baseline flowsheet cases (GF-1 and GF-3) on a DWPF scale.

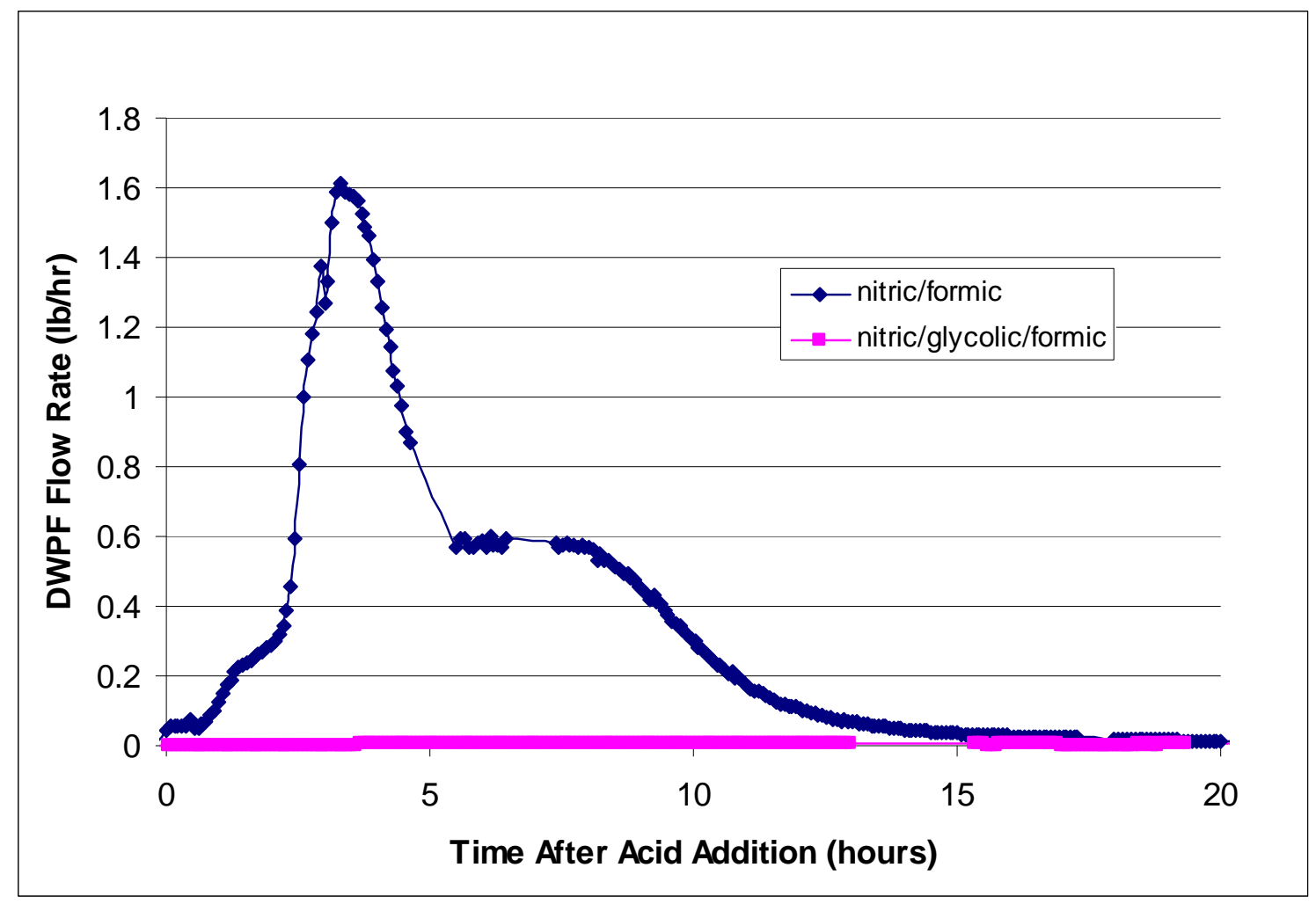

Figure 4. Baseline SRAT cycle hydrogen generation 


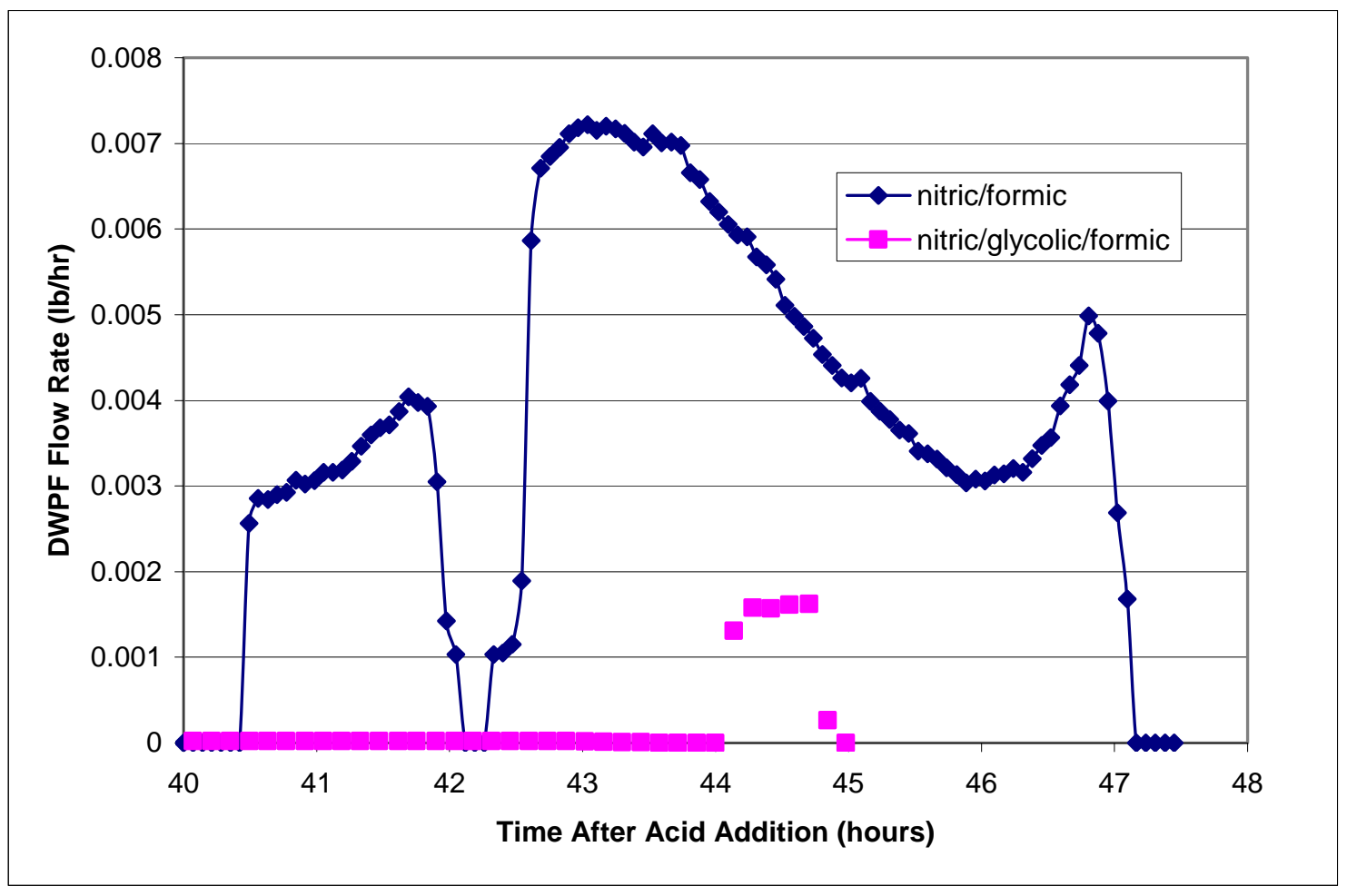

Figure 5. Baseline SME cycle hydrogen generation

Without mercury present (GF-2), some hydrogen was generated by processing with the glycolic/formic flowsheet. Hydrogen generation was slowly increasing near the end of reflux and appeared to plateau at a maximum of about 0.14 volume percent at the end of the SRAT cycle. A good deal more hydrogen was generated in the SME cycle, with a maximum near 0.65 volume percent. This is likely in part due to formic acid added with the frit. The hydrogen generation profile for the no mercury run is shown in the figure below. 
SRNL-STI-2010-00523

Revision 0

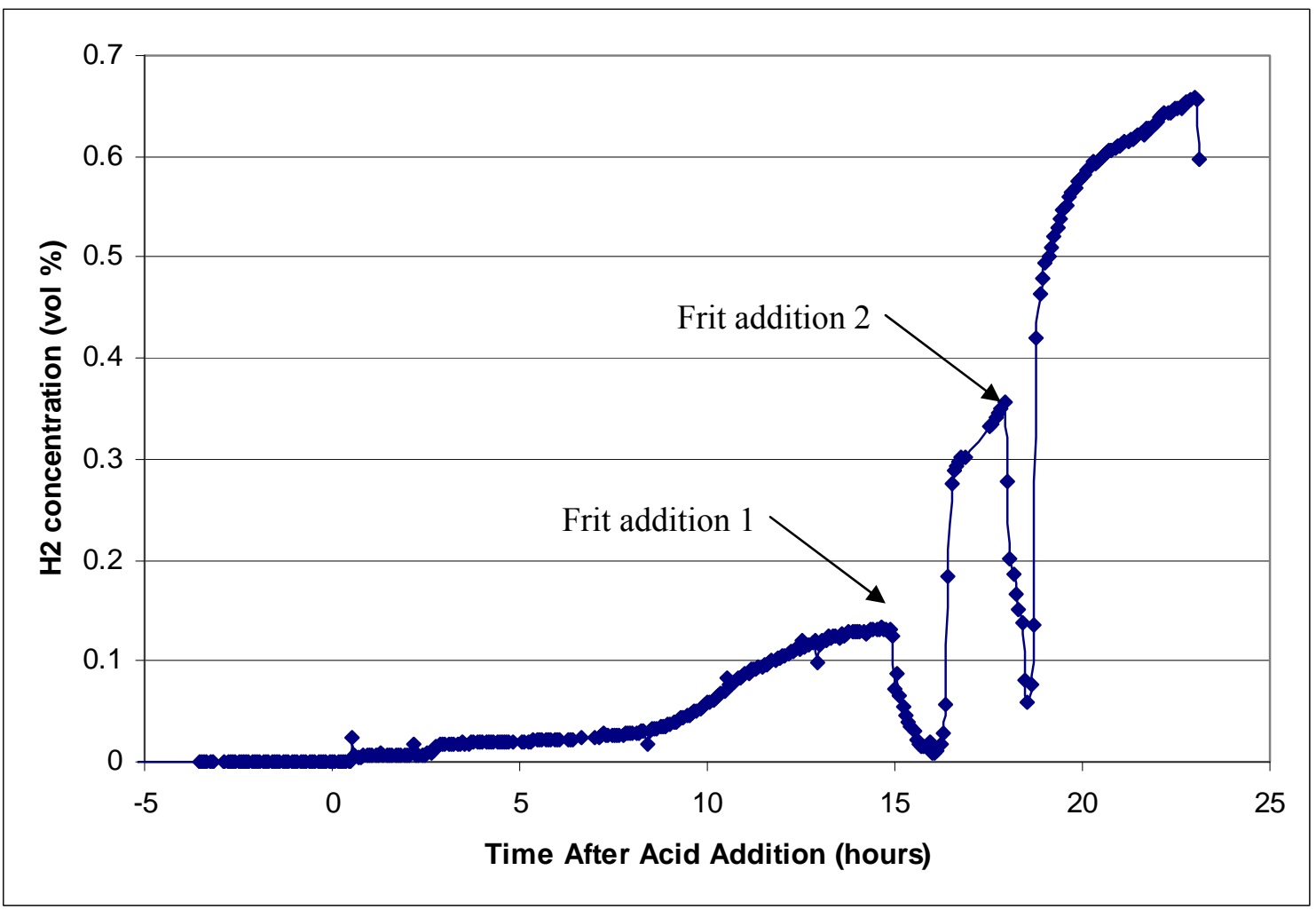

Figure 6. GF-2 (no Hg) hydrogen generation

Besides essentially eliminating hydrogen generation, the glycolic/formic acid flowsheet also appears to stop or significantly slow down other off-gas generating reactions. The graphs below compare $\mathrm{N}_{2} \mathrm{O}$ and $\mathrm{CO}_{2}$ generation rates for the two baseline flowsheet cases. The rapid fluctuations, especially in the nitric/formic case, can be attributed to the mixing issues experienced during acid addition. 


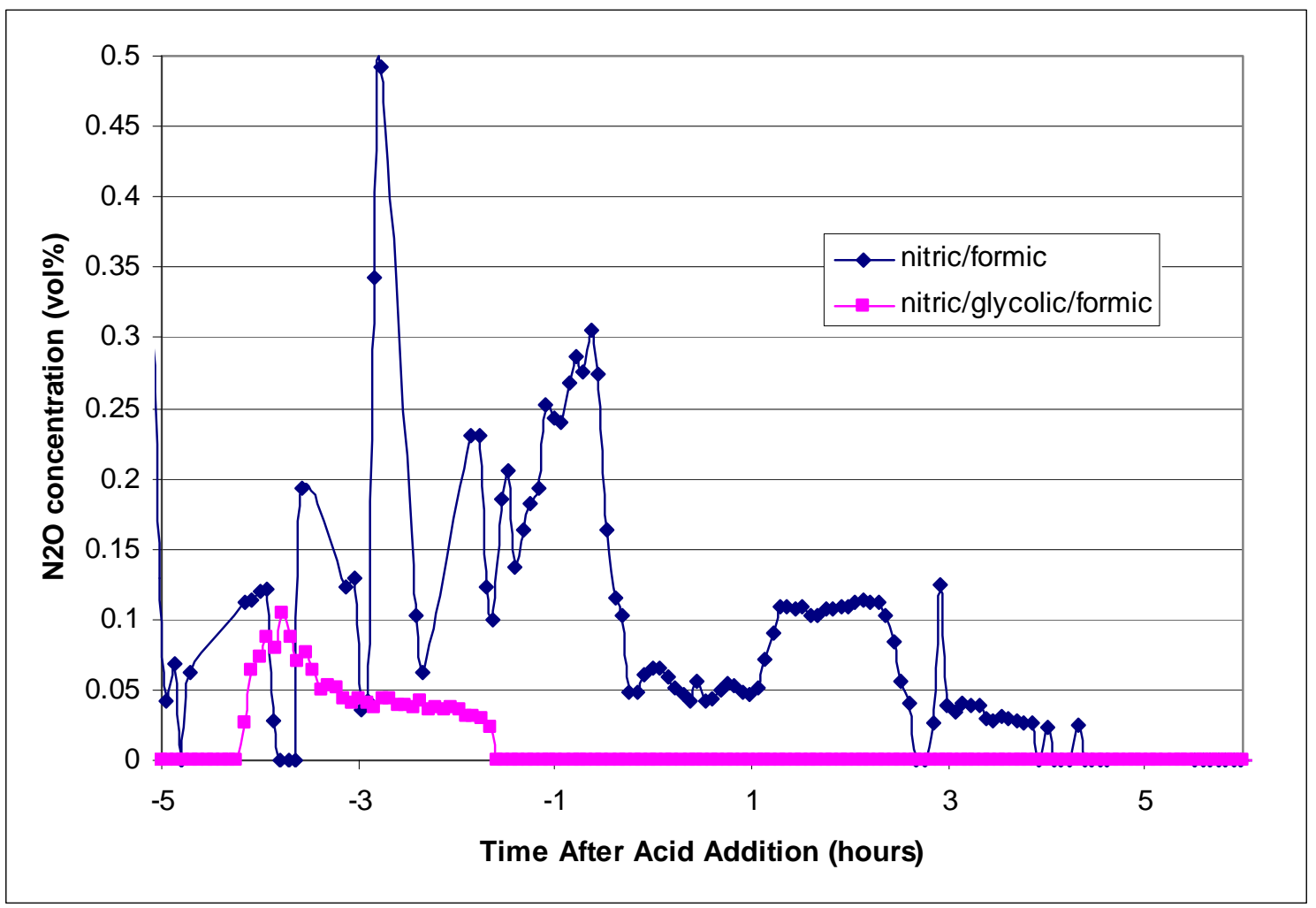

Figure 7. SRAT cycle $\mathrm{N}_{2} \mathrm{O}$ generation

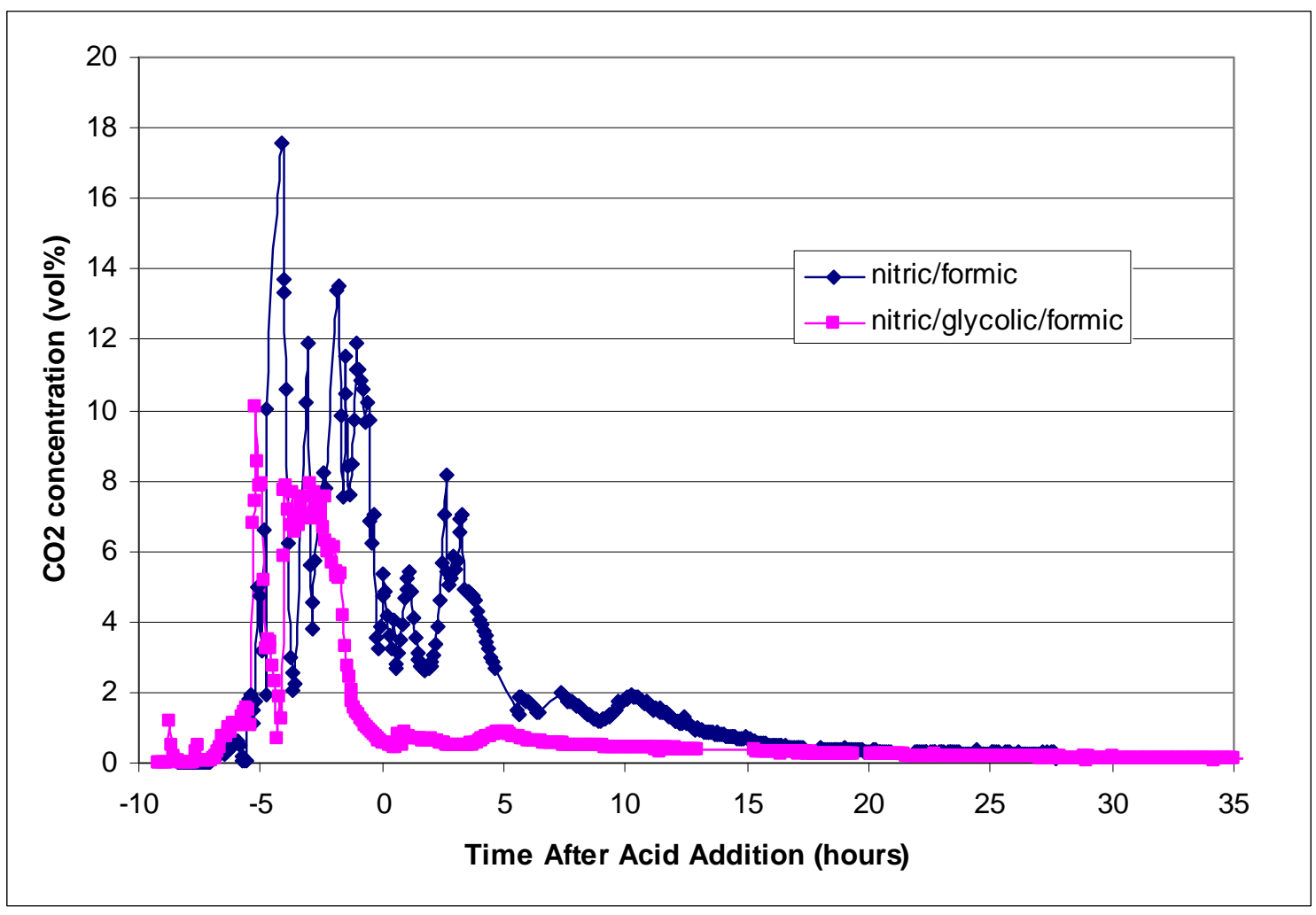

Figure 8. SRAT cycle CO2 generation 
Additional off-gas data can be found in Appendix A. As stated earlier, no significant off-gas generation was observed with any of the nitric/glycolic/formic flowsheet runs. GF-6 is shown below as an example.

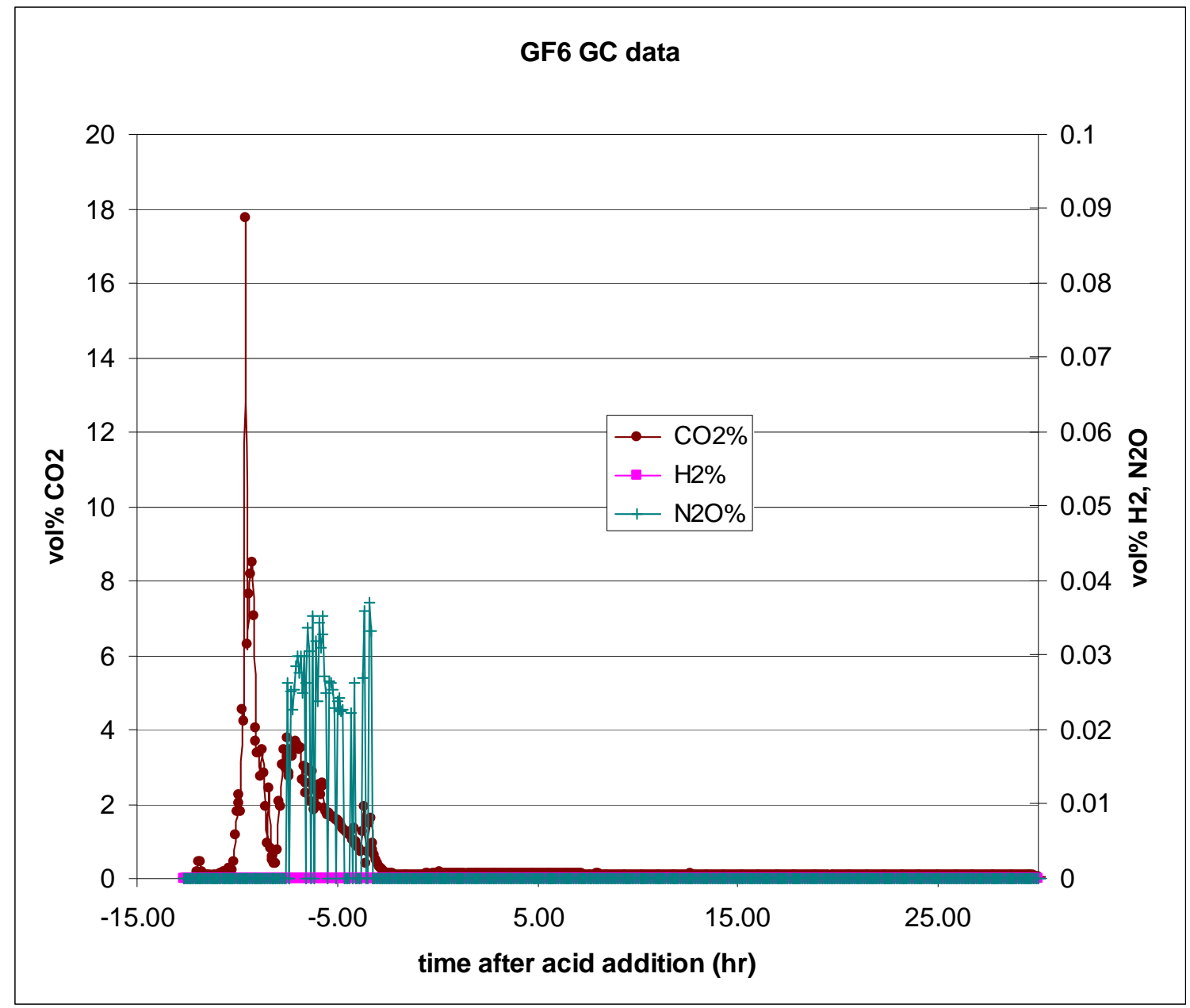

Figure 9. GF-6 GC Data

\subsection{Process Sample Data}

$\mathrm{pH}$ data was collected throughout the runs. The graph below shows the $\mathrm{pH}$ trends of the two baseline runs. The noise through the $5-7 \mathrm{pH}$ region further illustrate the mixing difficulties experienced during acid addition. 


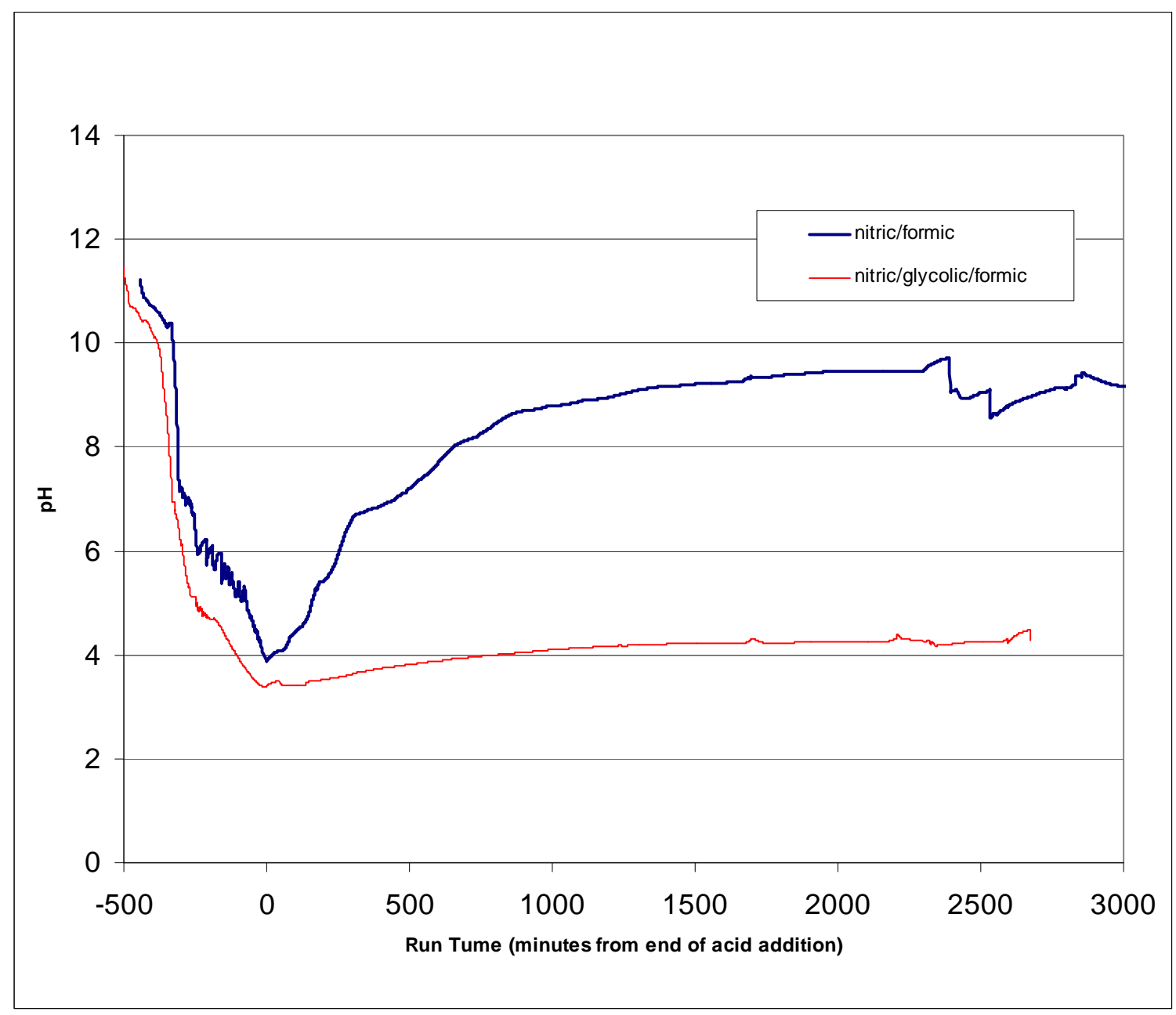

Figure 10. pH trends for baseline SRAT/SME runs

The additional nitric acid needed for REDOX balancing the glycolic/formic acid flowsheet runs causes the $\mathrm{pH}$ to be lower at the end of acid addition. During reflux, the catalytic destruction of formic acid which causes hydrogen generation in the current DWPF flowsheet causes the $\mathrm{pH}$ to increase as formic acid is consumed. Since this does not happen to nearly the same extent in the glycolic/formic flowsheet, the $\mathrm{pH}$ tends not to rebound as much during reflux. This leads to low pH SRAT and SME products which presents some additional concerns related to metal solubility that will be discussed later. A positive result of the low $\mathrm{pH}$ with the alternate flowsheet is that yield stress both during the process and of the products is low compared to the baseline flowsheet. Rheology data will also be presented later in this report.

General SRAT Product data for all eight runs are tabulated below. 
SRNL-STI-2010-00523

Revision 0

Table 3-2. Summary SRAT Product Data

\begin{tabular}{||c|cccccccc||}
\hline anions (mg/kg) & GF1 & GF2 & GF3 & GF4 & GF5 & GF6 & GF7 & GF8 \\
\hline \hline fluoride & $<100$ & $<100$ & $<100$ & $<100$ & $<100$ & $<100$ & $<100$ & $<100$ \\
chloride & 1085 & 1040 & 976 & 839 & 1002 & 1230 & 890 & 1210 \\
nitrite & $<100$ & $<100$ & $<100$ & $<100$ & $<100$ & $<100$ & $<100$ & $<100$ \\
nitrate & 25000 & 51600 & 55950 & 53100 & 59900 & 42250 & 59900 & 56250 \\
sulfate & 1920 & 1680 & 1765 & 2120 & 3275 & 2565 & 3280 & 3485 \\
glycolate & $<100$ & 53950 & 55400 & 56850 & 114500 & 65050 & 161500 & 118500 \\
oxalate & 296 & 649 & 2405 & 3910 & 2775 & 3395 & 1645 & 4680 \\
formate & 12900 & 2555 & $<100$ & $<100$ & 824 & 776 & 3750 & $<100$ \\
phosphate & $<100$ & $<100$ & $<100$ & $<100$ & $<100$ & $<100$ & $<100$ & $<100$ \\
\hline $\begin{array}{c}\text { wt\% total solids } \\
\text { wt\% calcined } \\
\text { solids }\end{array}$ & $17.53 \%$ & $21.77 \%$ & $21.79 \%$ & $22.32 \%$ & $24.03 \%$ & $25.59 \%$ & $21.75 \%$ & $24.62 \%$ \\
wt\% insoluble & $12.19 \%$ & $11.37 \%$ & $11.36 \%$ & $11.86 \%$ & $12.02 \%$ & $14.13 \%$ & $10.20 \%$ & $12.47 \%$ \\
$\begin{array}{c}\text { solids } \\
\text { wt\% soluble } \\
\text { solids }\end{array}$ & $11.01 \%$ & $8.76 \%$ & $8.98 \%$ & $8.84 \%$ & $10.23 \%$ & $11.20 \%$ & $5.96 \%$ & $10.83 \%$ \\
\hline $\begin{array}{c}\text { density (g/mL) } \\
\text { pH at 25 }{ }^{\circ} \mathbf{C}\end{array}$ & $1.53 \%$ & $13.01 \%$ & $12.80 \%$ & $13.48 \%$ & $13.80 \%$ & $14.39 \%$ & $15.79 \%$ & $13.80 \%$ \\
\hline \hline
\end{tabular}

The oxalate results are of particular interest. The starting sludge contains about $800 \mathrm{mg} / \mathrm{kg}$ oxalate, which is generally assumed to be at least partially destroyed during the SRAT cycle. In the glycolic/formic flowsheet runs, however, oxalate is being created. As postulated earlier in this report, it is possible that glycolic acid is oxidized to glyoxylic acid by nitrite or $\mathrm{MnO}_{2}$, which is further oxidized to oxalic acid by the reduction of mercury. This also would explain the lack of oxalate generation in the run without mercury, GF-2.

These runs represent the first time that glycolate ion measurements were performed on actual SRAT/SME products, as opposed to spiked samples and simple solutions. A separate report has been drafted detailing the glycolate IC method development. ${ }^{8}$ It appears from the data presented here that the second set of runs (GF-5-8) may be biased high in glycolate. The $65050 \mathrm{mg} / \mathrm{kg}$ measured for GF6 represents $99.6 \%$ of the total moles of glycolate added during the SRAT. This is unrealistically high, especially if the proposed pathway for oxalate formation is correct. The results for GF-5,-7, and -8 show more glycolate in the SRAT product than was added. Resolving this issue so that reliable glycolate data is available will be especially important for refining the REDOX model as flowsheet development continues.

Anion balance data for nitrite, nitrate, formate and glycolate are presented in the table below. 
Table 3-3. Anion Balance Data

\begin{tabular}{|c|cccccccc|}
\hline & GF1 & GF2 & GF3 & GF4 & GF5 & GF6 & GF7 & GF8 \\
\hline $\begin{array}{c}\text { SRAT Formate } \\
\text { Destruction (\%) }\end{array}$ & 78.7 & 71.4 & 100 & 100 & 94.0 & 92.1 & 71.3 & N/A \\
$\begin{array}{c}\text { SRAT Nitrite } \\
\text { Destruction (\%) }\end{array}$ & 100 & 100 & 100 & 100 & 100 & 100 & 100 & 100 \\
SRAT Glycolate & N/A & 9.3 & 11.7 & 4.5 & -24.2 & 0.4 & -85.0 & -80.0 \\
$\begin{array}{c}\text { Destruction (\%) } \\
\text { SRAT Nitrite to } \\
\text { Nitrate }\end{array}$ & 18.9 & 44.4 & 51.4 & 46.4 & -0.2 & 27.1 & -3.2 & 73.5 \\
$\begin{array}{c}\text { Conversion (\%) } \\
\text { SME Formate } \\
\text { Destruction (\%) }\end{array}$ & -3.5 & 44.3 & 100 & 41.5 & 61.8 & 42.6 & 62.2 & N/A \\
$\begin{array}{c}\text { SME Nitrate } \\
\text { Destruction (\%) } \\
\text { SME Glycolate } \\
\text { Destruction (\%) }\end{array}$ & 25.6 & 9.7 & 9.3 & 9.9 & -2.5 & 10.1 & 21.8 & N/A \\
\hline
\end{tabular}

Full elemental analyses are presented in Appendix A. Some SME product data are presented in Section 3.5.

As noted earlier, the low SRAT/SME product $\mathrm{pH}$ in the glycolic/formic flowsheet runs causes some elements that are normally insoluble to become soluble. Of particular concern is iron solubility because criticality control at DWPF is based on iron and plutonium not partitioning between the solids and supernate. The chart below shows iron solubility as a function of acid stoichiometry for the nitric/glycolic/formic acid flowsheet with the baseline nitric/formic run as a point of comparison. 
SRNL-STI-2010-00523

Revision 0

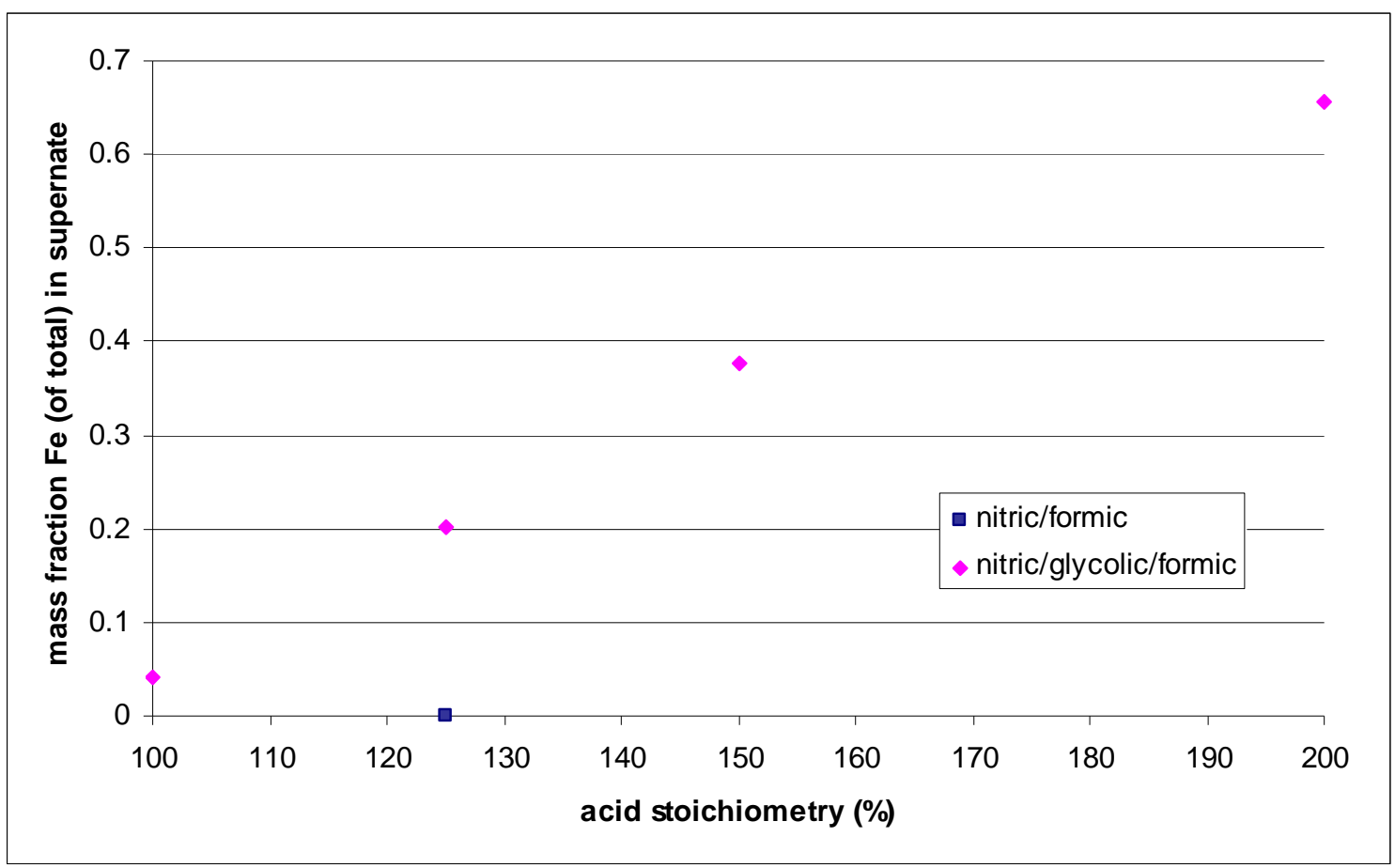

Figure 11. Iron solubility as a function of acid stoichiometry

Other elements also show significantly higher solubility in the glycolic/formic flowsheet runs, including $\mathrm{Ca}, \mathrm{Cu}, \mathrm{Mg}, \mathrm{Mn}, \mathrm{Ni}, \mathrm{Sr}$ and $\mathrm{Zr}$. The table below shows the amount of each element found in the SRAT product supernate expressed as a percentage of the total element present. These data are calculated by dividing the supernate concentration by the total slurry fraction of each element. Numbers greater than $100 \%$ are not physically possible and are a result of error in one of the analytical measurements used in the calculation.

Table 3-4. SRAT Product Supernate \% of Element Dissolved

\begin{tabular}{||l|c|c|c|c|c|c|c|c|c||}
\hline & $\underline{\mathbf{A l}}$ & $\underline{\mathbf{C a}}$ & $\underline{\mathbf{C u}}$ & $\underline{\mathbf{F e}}$ & $\underline{\mathbf{M g}}$ & $\underline{\mathbf{M n}}$ & $\underline{\mathbf{N i}}$ & $\underline{\mathbf{S r}}$ & $\underline{\mathbf{Z r}}$ \\
\hline GF1 & $0.0 \%$ & $8.8 \%$ & $0.0 \%$ & $0.0 \%$ & $1.8 \%$ & $0.0 \%$ & $0.0 \%$ & $0.0 \%$ & $0.0 \%$ \\
\hline GF2 & $4.9 \%$ & $130.8 \%$ & $83.5 \%$ & $18.1 \%$ & $70.1 \%$ & $82.6 \%$ & $58.9 \%$ & $87.8 \%$ & $45.7 \%$ \\
\hline GF3 & $4.9 \%$ & $127.9 \%$ & $92.0 \%$ & $20.1 \%$ & $73.2 \%$ & $82.1 \%$ & $61.7 \%$ & $89.9 \%$ & $47.7 \%$ \\
\hline GF4 & $5.9 \%$ & $97.6 \%$ & $69.2 \%$ & $8.7 \%$ & $72.9 \%$ & $62.4 \%$ & $45.8 \%$ & $64.1 \%$ & $9.8 \%$ \\
\hline GF5 & $5.3 \%$ & $129.5 \%$ & $103.5 \%$ & $37.7 \%$ & $84.6 \%$ & $72.0 \%$ & $89.6 \%$ & $99.1 \%$ & $55.7 \%$ \\
\hline GF6 & $2.2 \%$ & $116.4 \%$ & $20.8 \%$ & $4.1 \%$ & $44.0 \%$ & $99.0 \%$ & $29.3 \%$ & $84.7 \%$ & $17.7 \%$ \\
\hline GF7 & $14.5 \%$ & $138.2 \%$ & $109.4 \%$ & $65.7 \%$ & $92.4 \%$ & $91.2 \%$ & $92.7 \%$ & $106.7 \%$ & $82.0 \%$ \\
\hline GF8 & $9.4 \%$ & $129.3 \%$ & $95.9 \%$ & $17.3 \%$ & $79.6 \%$ & $71.2 \%$ & $81.5 \%$ & $93.6 \%$ & $60.7 \%$ \\
\hline
\end{tabular}

Further work is required to determine a limit for iron solubility. Processing at a lower acid stoichiometry will cause fewer metals to become soluble. Additionally, the use of gadolinium as a substitute neutron poison is being pursued. The solubility of gadolinium with the glycolic/formic acid flowsheet should also be investigated. 


\subsection{Glass REDOX}

SME product samples were vitrified in closed crucibles and the resulting glasses measured for REDOX $\left(\mathrm{Fe}^{2+} / \Sigma \mathrm{Fe}\right)$. The REDOX target for all the simulations in this study was 0.2 . The target is achieved by predicting the SME product anion concentrations and adjusting the split of acids between nitric and glycolic/formic. Therefore the ability to hit a REDOX target is highly dependent on being able to accurately predict anion behavior in the SRAT and SME cycles. Inserting the SME product data into the latest REDOX correlation gives a "predicted" REDOX that is different than the targeted REDOX of 0.2. The table below shows the appropriate SME product data with the corresponding predicted REDOX values as well as the REDOX as measured.

Table 3-5. SME product data for REDOX calculations

\begin{tabular}{|c|c|c|c|c|c|c|c|}
\hline anions (mg/kg) & GF1 & GF2 & GF3 & GF4 & GF5 & GF6 & GF7 \\
\hline fluoride & $<100$ & $<100$ & $<100$ & $<100$ & $<100$ & $<100$ & $<100$ \\
\hline chloride & 1390 & 1065 & $<100$ & 896.5 & 1070 & 1160 & 1045 \\
\hline nitrite & $<100$ & $<100$ & $<100$ & $<100$ & $<100$ & $<100$ & $<100$ \\
\hline nitrate & 25350 & 54950 & 53100 & 47150 & 64750 & 42900 & 69600 \\
\hline sulfate & 2475 & 1790 & 1855 & 2285 & 3680 & 2335 & 3530 \\
\hline glycolate & 0 & 57000 & 52550 & 58100 & 102000 & 65250 & 154000 \\
\hline oxalate & 519.5 & 737 & 2690 & 4185 & 3500 & 4105 & 2175 \\
\hline formate & 22200 & 3470 & $<100$ & 937 & 1700 & 2525 & 3455 \\
\hline phosphate & $<100$ & $<100$ & $<100$ & $<100$ & $<100$ & $<100$ & $<100$ \\
\hline \multicolumn{8}{|l|}{ Other properties } \\
\hline Mn (gmol/kg slurry) & 0.167 & 0.140 & 0.136 & 0.115 & 0.172 & 0.181 & 0.141 \\
\hline wt $\%$ total solids & $46.28 \%$ & $44.95 \%$ & $44.66 \%$ & $45.18 \%$ & $49.73 \%$ & $52.70 \%$ & $47.04 \%$ \\
\hline predicted redox & -0.128 & 0.159 & 0.108 & 0.336 & 0.654 & 0.432 & 1.432 \\
\hline measured redox & 0.000 & 0.661 & 0.750 & 0.612 & 0.751 & 0.528 & 0.877 \\
\hline $\begin{array}{c}\text { stoichiometry (\% } \\
\text { Koopman } \\
\text { minimum) } \\
\end{array}$ & 125 & 125 & 125 & 125 & 150 & 100 & 200 \\
\hline
\end{tabular}

Note that because the REDOX model is a linear regression equation, values less than zero or greater than one can be calculated. This is physically impossible, however. A number less than zero can be interpreted as fully oxidized and likewise a number greater than one fully reduced.

Analysis of these data leads to two conclusions. First, predicted REDOX based on SME product data vary significantly from the targeted 0.2 . Secondly, measured REDOX does not agree well with predicted REDOX.

The first conclusion points to errors in predicting anion conversion factors. This is not entirely unexpected for runs with a previously untested sludge and a new flowsheet. The results from these runs and in particular the $100 \%$ acid run can be used to generate new predictions for future work.

The second conclusion indicates error in either the applicability of the REDOX model in this compositional space, the IC data, or the REDOX test method itself. By spiking samples with known amounts of additional glycolate or nitrate and re-measuring REDOX, the potential errors 
in the IC measurement can be negated. This test has been done and additional runs to determine whether new processing assumptions will lead to better REDOX control are underway. These experiments will be documented separately at a later date.

A plot of measured REDOX against acid stoichiometry as shown below indicates that increasing acid leads to linearly increasing REDOX. This strong correlation means that once the appropriate anion predictions are determined, the REDOX should be predictable. The ability to control REDOX once it can be accurately predicted depends on the quality of the SME product glycolate predictions and the amount of acid added. The less acid added, the smaller the effect conversion factor errors will have on the final REDOX.

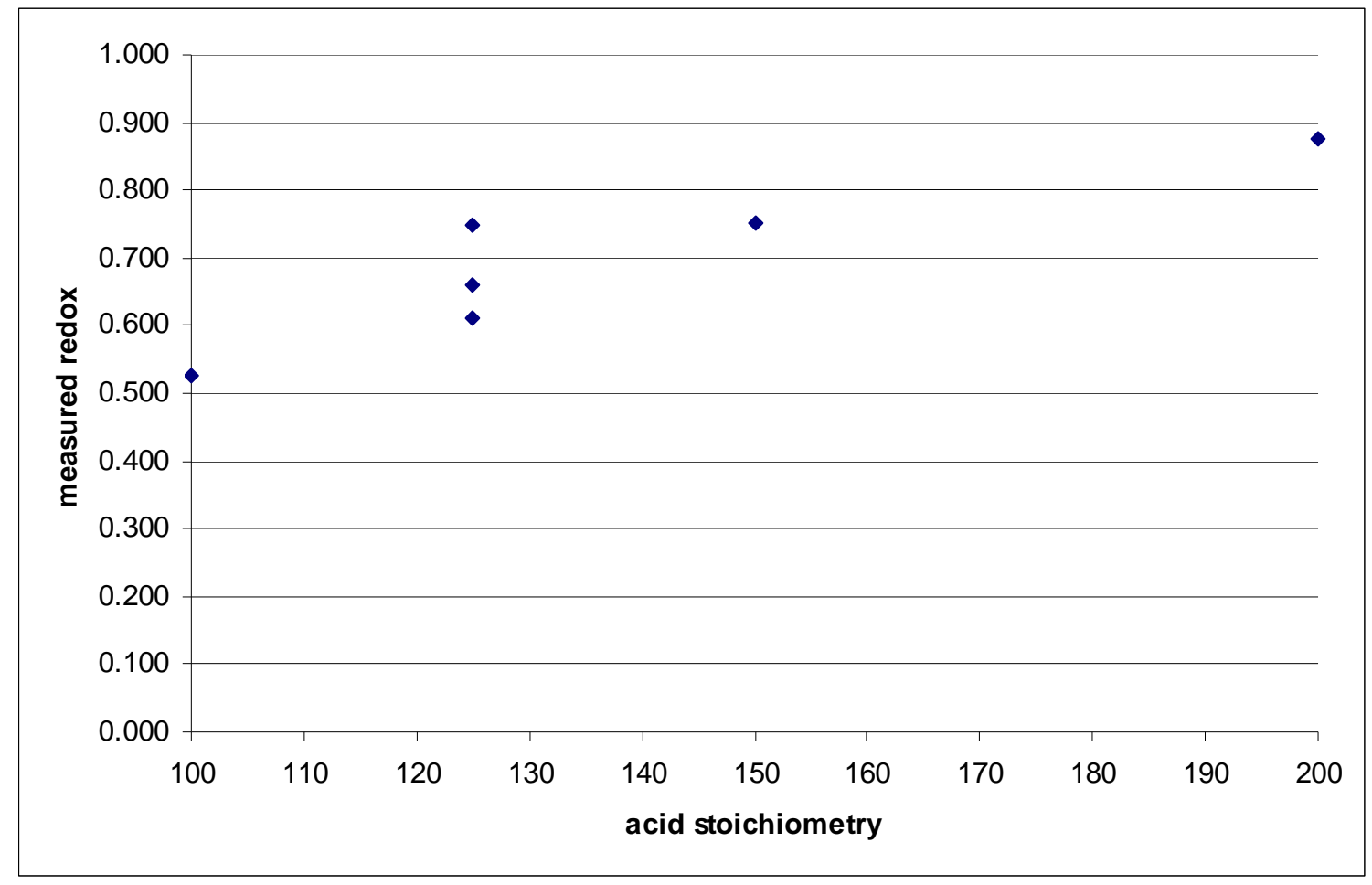

Figure 12. Measured REDOX dependence on acid stoichiometry

\subsection{Rheology}

Flow curves for the SRAT and SME products were obtained by using a Hake RS600 rheometer and the current DWPF simulant rheology protocol. The up and down curves were fit to a Bingham plastic model to determine yield stress and consistency. The data for all runs are tabulated below along with a graphical comparison of the flow curves for the two baseline runs. 
Table 3-6. SRAT Product Rheology Summary

\begin{tabular}{|l|l|l|l|l|l|l|l|l||}
\hline & GF-1 & GF-2 & GF-3 & GF-4 & GF-5 & GF-6 & GF-7 & GF-8 \\
\hline Up yield stress, Pa & 33.8 & 1.3 & 1.6 & 0.9 & 2.8 & 6.1 & 7.8 & 1.5 \\
\hline Up consistency, cP & 22.2 & 6.6 & 7.1 & 5.0 & 10.1 & 14.8 & 10.3 & 6.4 \\
\hline Down yield stress, Pa & 33.1 & 1.3 & 1.6 & 0.9 & 3.0 & 6.1 & 6.8 & 1.6 \\
\hline Down consistency, cP & 22.8 & 6.6 & 7.1 & 5.0 & 10.5 & 14.8 & 11.0 & 6.4 \\
\hline
\end{tabular}

Table 3-7. SME Product Rheology Summary

\begin{tabular}{|l|l|l|l|l|l|l|l||}
\hline & GF-1 & GF-2 & GF-3 & GF-4 & GF-5 & GF-6 & GF-7 \\
\hline Up yield stress, Pa & 334.4 & 6.1 & 6.7 & 3.5 & 22.1 & 32.0 & 44.0 \\
\hline Up consistency, cP & -63.6 & 22.5 & 24.5 & 17.3 & 58.3 & 85.4 & 60.9 \\
\hline Down yield stress, Pa & 223.0 & 6.8 & 7.2 & 3.3 & 23.9 & 30.2 & 41.0 \\
\hline Down consistency, cP & 289.0 & 21.7 & 24.1 & 18.3 & 51.9 & 89.2 & 69.2 \\
\hline
\end{tabular}

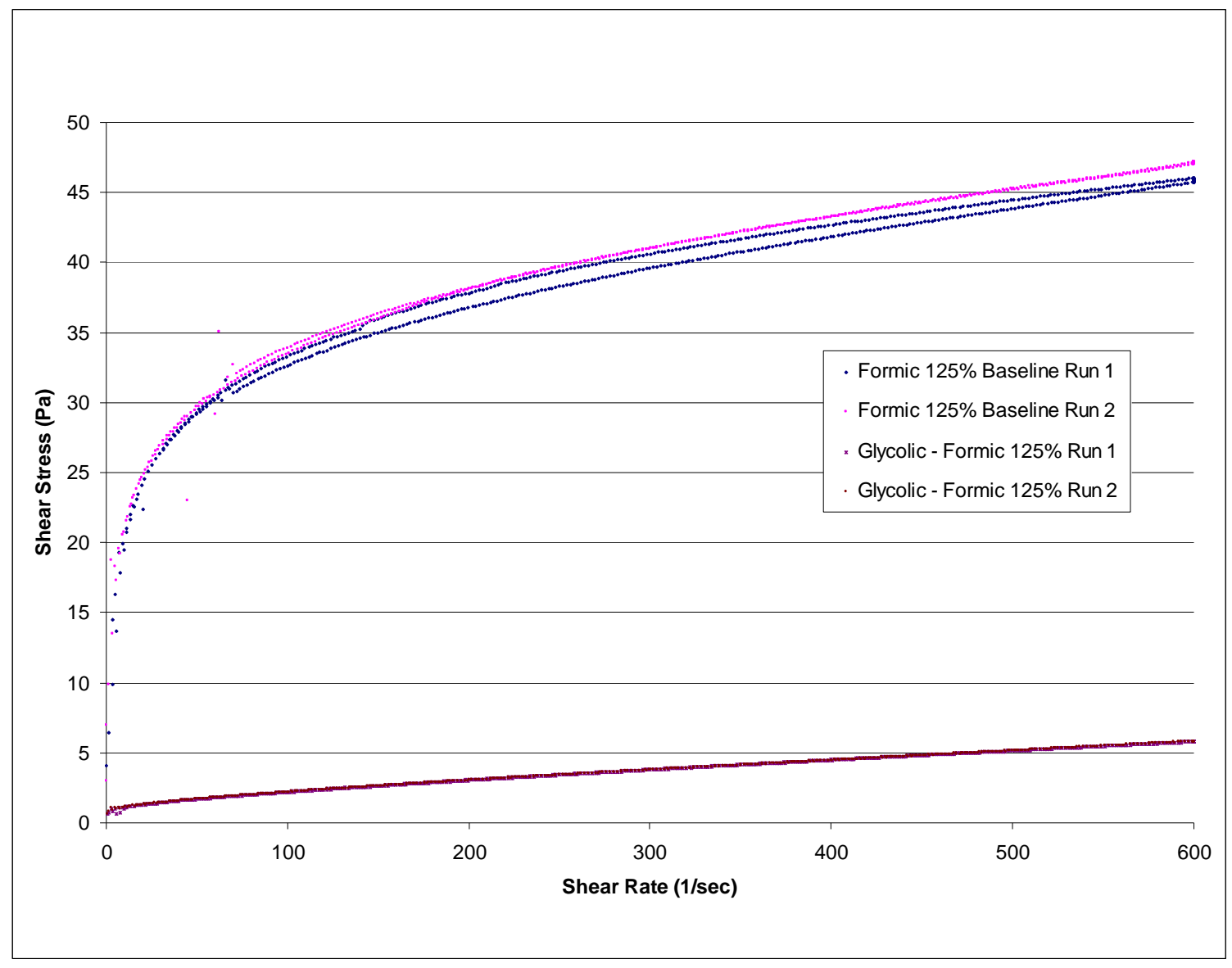

Figure 13. SRAT Product flow curve comparison

The baseline nitric/formic flowsheet run far exceeds both the SRAT and SME design basis limits for yield stress and consistency. The baseline formic/glycolic run was within limits. The negative value for SME consistency in the baseline run indicates a large hump in the up curve, therefore the values for the down curve are more representative. Yield stress for GF-7 is higher than that for GF-5 or GF-6 despite having more acid added and lower insoluble solids. This 
could be because the slurry chemistry is different at such a high acid stoichiometry or it could be sampling or analytical error.

\subsection{Volatile Organic Content}

Condensate samples were analyzed by SRNL AD for volatile and semi-volatile organics to ensure that there are no new degradation products formed by glycolic acid that could present downstream issues to the Tank Farm. No semi-volatile organics were found in any of the samples. Small amounts (ranging from $5-15 \mathrm{mg} / \mathrm{L}$ ) of siloxanes, primarily hexamethyldisiloxane, were found in all the samples. This is consistent with antifoam degradation and is not unique to the glycolic/formic acid flowsheet.

\subsection{Conclusions}

Flowsheet testing was performed to further develop the nitric/glycolic/formic acid flowsheet as an alternative to the nitric/formic flowsheet currently being processed at the DWPF. This new flowsheet has shown that mercury can be removed in the SRAT with minimal hydrogen generation. All other processing objectives were also met, including greatly reducing the SME product yield stress as compared to the baseline nitric/formic flowsheet. Eight runs were performed in total, including the baseline run.

The baseline nitric/formic flowsheet run would be considered a failure under existing DWPF acceptance criteria with this simulant at the HM levels of noble metals. While nitrite was destroyed and mercury was removed to near the DWPF limit, the rheology of the SRAT and SME products are well above design basis and hydrogen generation far exceeded the DWPF limit. In addition, mixing during the SME cycle was very poor. In this sense, the nitric/glycolic/formic acid flowsheet represents a significant upgrade over the current flowsheet. Mercury was successfully removed with almost no hydrogen generation and the SRAT and SME products yield stresses were within process limits or previously processed ranges.

Two areas for future study related to the glycolic/formic flowsheet were raised during this testing. Iron was dissolved to varying extents because of the relatively higher amount of nitric acid used as compared to the standard flowsheet. Iron solubility may be a potential concern for DWPF processing since it is presently credited for criticality control in the SRAT with an assumption that it and plutonium both remain relatively insoluble during processing.

The second area is that of REDOX control. REDOX targets were missed and the predicted REDOX from SME product results varied significantly from the measured REDOX in all cases. This difference is not unusual for a new sludge batch or with a new flowsheet, but it is an area that needs to be further understood. This understanding will be contingent upon a reliable analytical method for glycolate ion measurement in SRAT/SME products.

In addition to mitigating hydrogen generation, other off-gas generating reactions were minimized by the new flowsheet. This could potentially allow DWPF to increase steam rate to speed up SRAT processing due to less delta $\mathrm{P}$ across the SRAT. No glycolic acid by-products were found in the condensate streams that would lead to downstream issues in the Tank Farm.

While the $125 \%$ acid stoichiometry run was taken as the baseline for the purpose of comparison, review of all the data presented to this point indicates that the $100 \%$ stoichiometry run should be used as the basis for future flowsheet development. In this run, mercury was effectively removed with no hydrogen generation and some of the unintended side effects of the glycolic/formic acid 
flowsheet with high acid stoichiometry were minimized. In the $100 \%$ run, only $4 \%$ of the iron was soluble and yield stress was still within design basis or previously processed ranges. Also, adding less acid will tend to minimize the effect of errors in processing assumptions leading to unpredictable glass REDOX.

\subsection{Recommendations and Future Work}

It is recommended that DWPF continue to support development of the glycolic/formic flowsheet. In the still very limited amount of testing that has been performed to date, this flowsheet meets or outperforms the current flowsheet in many regards, including off-gas generation, mercury removal, product rheology and general ease of processing.

A few issues still need to be resolved prior to implementation. Analysis of the mercury collected during the glycolic/formic runs should be performed. The mercury appeared "dirty" compared to the mercury collected in nitric/formic flowsheet runs. While this has been observed before in standard flowsheet runs, the issue appears to be exacerbated by the low $\mathrm{pH}$ reached in the glycolic/formic runs. The tendency of this mercury not to coalesce and stick in the overheads is of potential concern.

Additional testing to verify the ability to control REDOX needs to be performed. This work has already been started at the time this report was being written. After the REDOX issue is addressed, testing over varying sludge compositions should be performed to test the robustness of the flowsheet. Additionally, testing to understand iron and gadolinium solubility behavior for this flowsheet should be done. This work has also already started.

The glycolate IC method could be benefited by further refinement. Shortening the method cycle time and an overall improvement of accuracy would be very beneficial for both continued SRNL testing and eventual DWPF implementation. 
SRNL-STI-2010-00523

Revision 0

\subsection{References}

${ }^{1}$ Pickenheim, B.R., M.E. Stone, D.K. Peeler, Selection and Preliminary Evaluation of Alternative Reductants for SRAT Processing, SRNL-STI-2009-00120, Savannah River National Laboratory, Aiken, SC, February 2009.

${ }^{2}$ Holtzscheiter, E. W. Technical Task Request - Slurry Receipt and Adjustment Tank (SRAT) Alternative Reductant Assessment, HLW-DWPF-TTR-2008-0039, Washington Savannah River Company, Aiken, SC, 2008.

${ }^{3}$ Pickenheim, B.R., Task Technical and Quality Assurance Plan for Glycolic-Formic Acid Flowsheet Development, Definition and Demonstration Tasks 4-5, SRNL-RP-2009-00484, Savannah River National Laboratory, Aiken, SC, April 2010.

${ }^{4}$ Fernandez, A.I., SB6-H Simulant Development: Evaluation Memo, SRNL-L3100-2010-00159, Savannah River National Laboratory, Aiken, SC, August 2010.

5 Koopman, D.C., A.I. Fernandez and B.R. Pickenheim, Preliminary Evaluatoins of Two Proposed Stoichiometric Acid Equations, SRNL-L3100-2009-00146, Savannah River National Laboratory, Aiken, SC, 2009

${ }^{6}$ Jantzen, C.M. and M.E. Stone, Role of Manganese Reduction/Oxidation (RedOx) on Foaming and Melt Rate in High Level Waste Melters, WSRC-STI-2006-00066, Savannah River Site, Aiken, SC, March 2007.

${ }^{7}$ Koopman, D.C., Sludge Batch 6/Tank 40 Simulant Chemical Process Cell Simulations, SRNL-STI-201000212, Savannah River National Laboratory, Aiken, SC, April 2010.

${ }^{8}$ Best, D.R., Anion Analysis by Ion Chromatography for the Alternate Reductant Program for the Defense Waste Processing Facility, SRNL-STI-2010-00389, Savannah River National Laboratory, Aiken, SC, June 2010. 
SRNL-STI-2010-00523

Revision 0

Appendix A 


\section{A.1 Mercury Removal Plots}

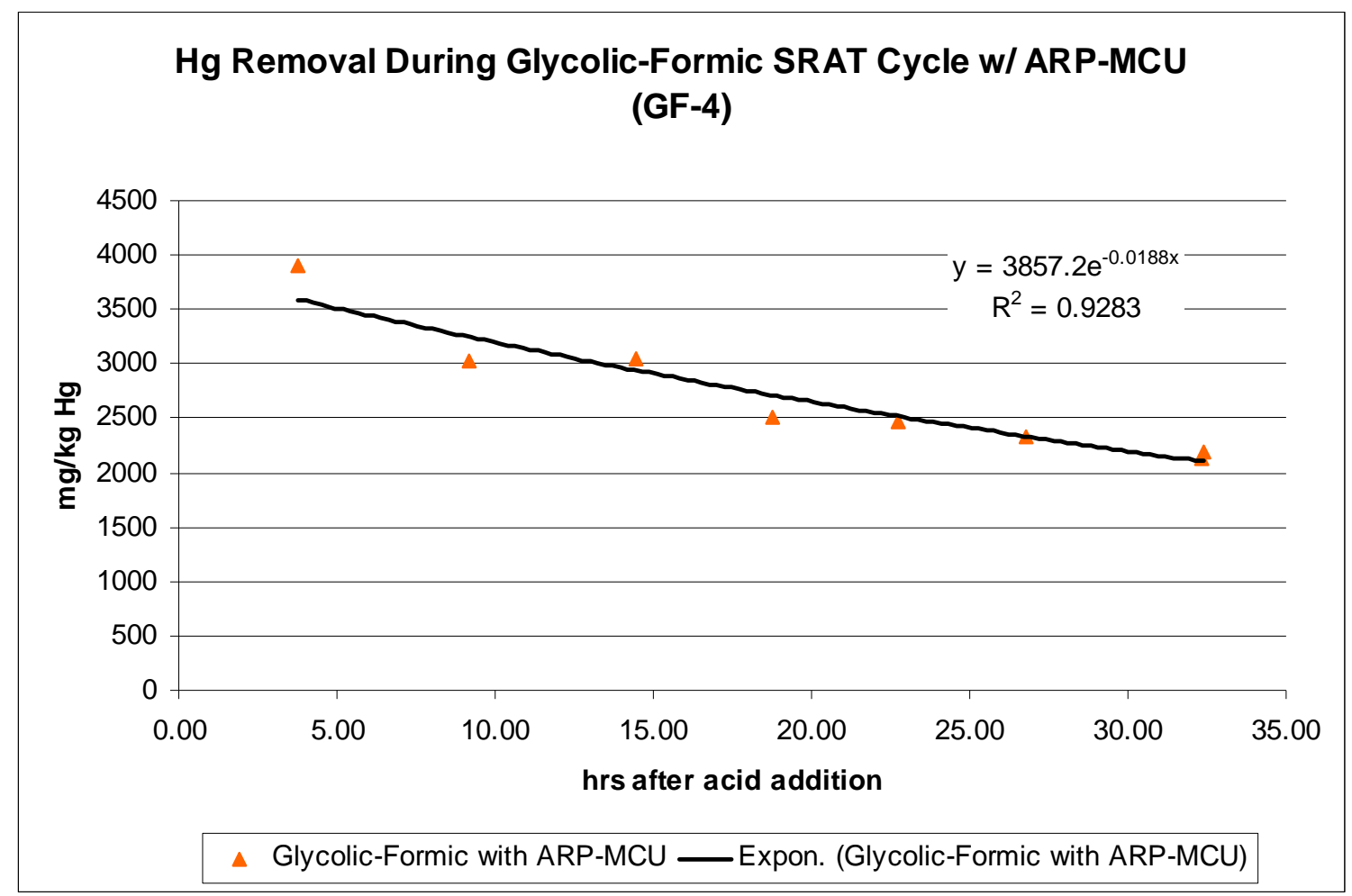



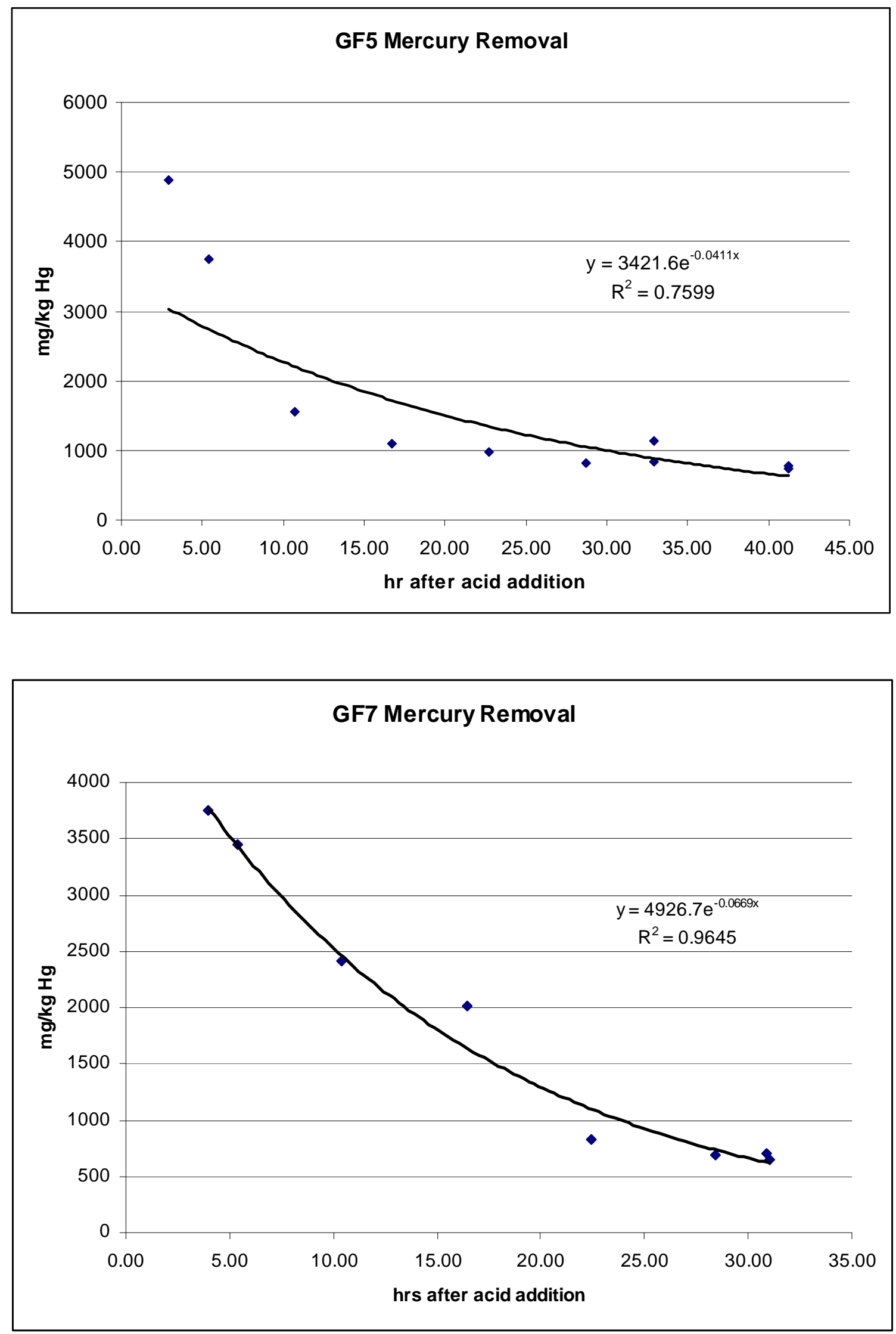


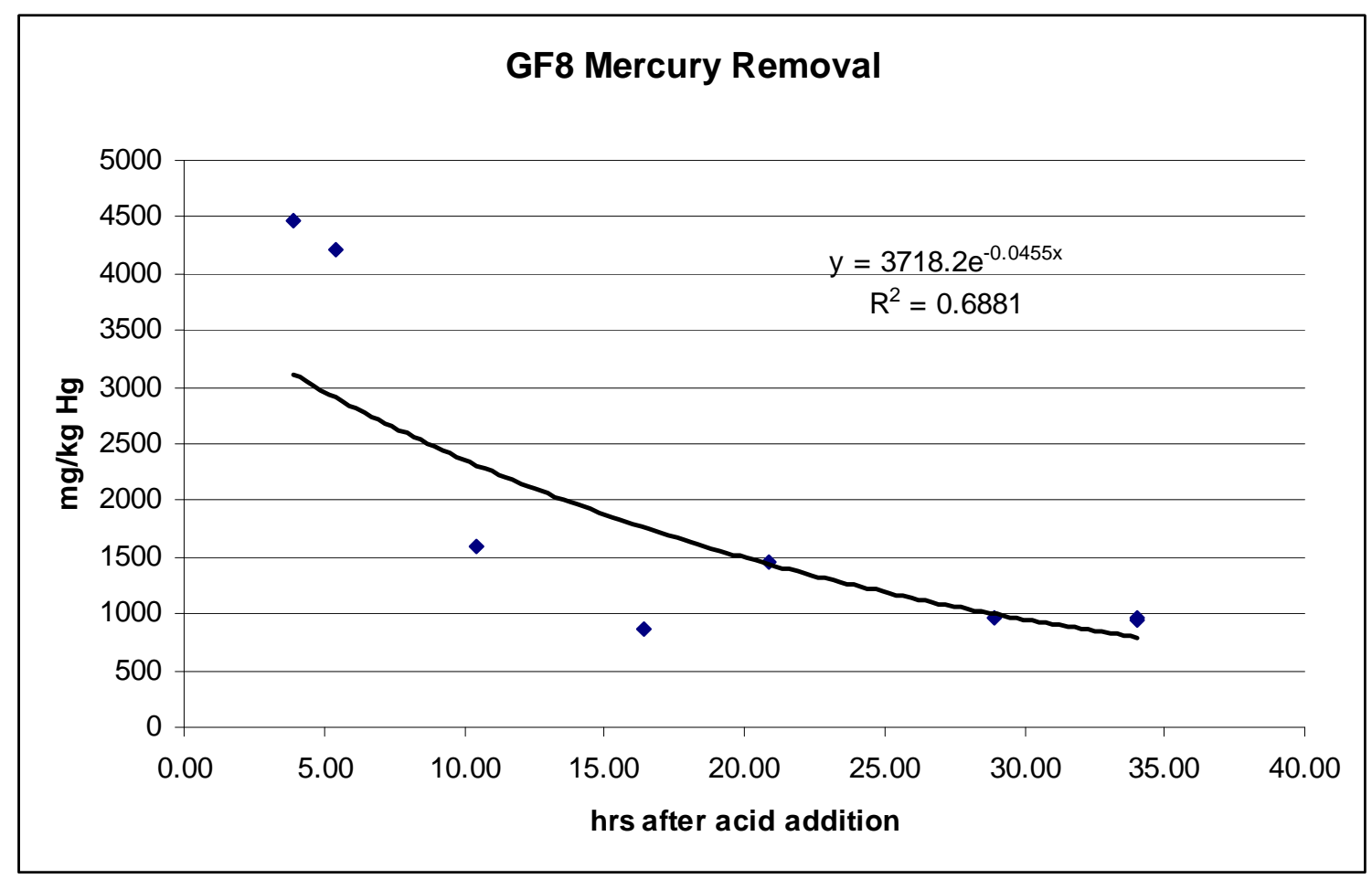


SRNL-STI-2010-00523

Revision 0

\section{A.2 Rheology Flow Curves}

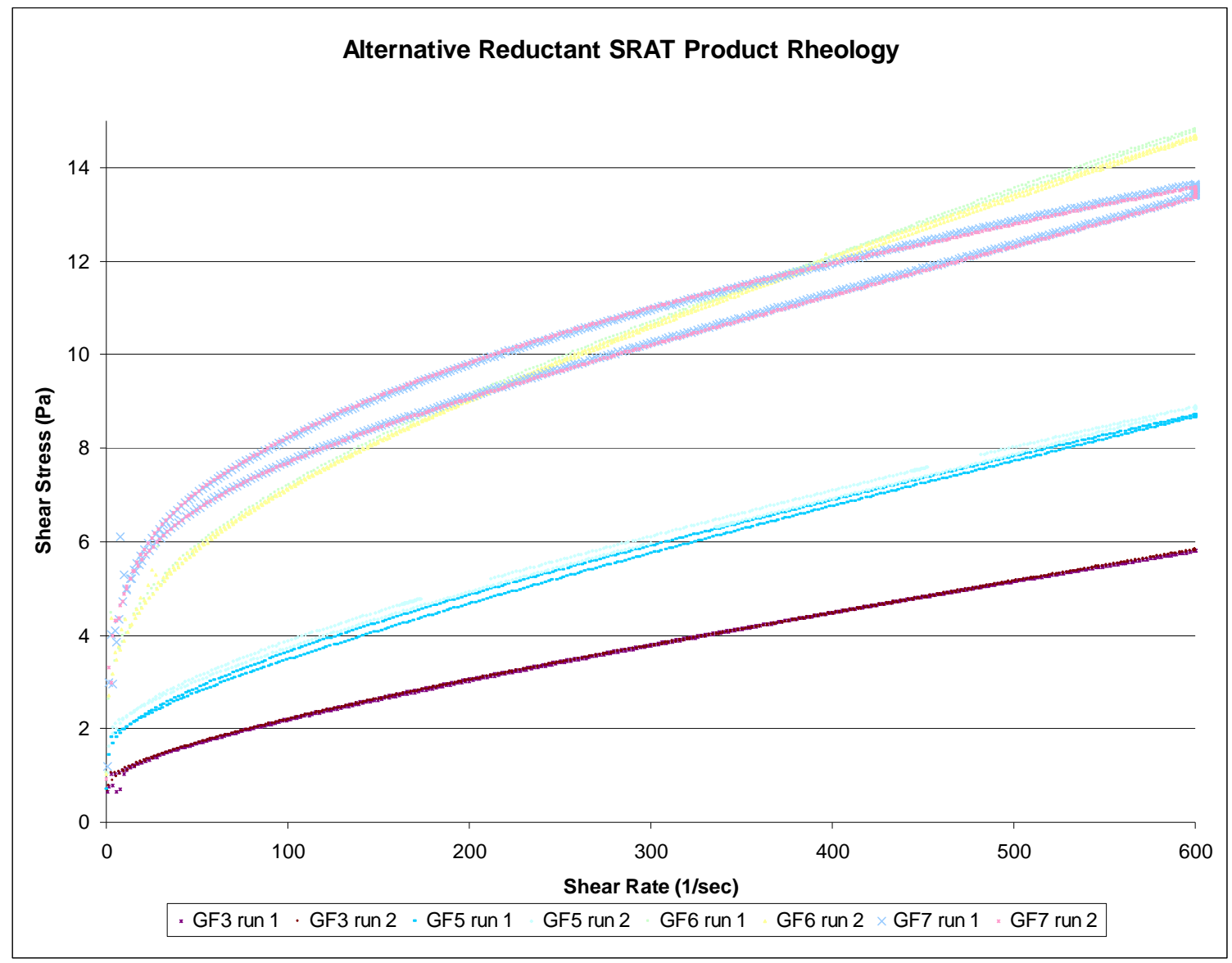


SRNL-STI-2010-00523

Revision 0

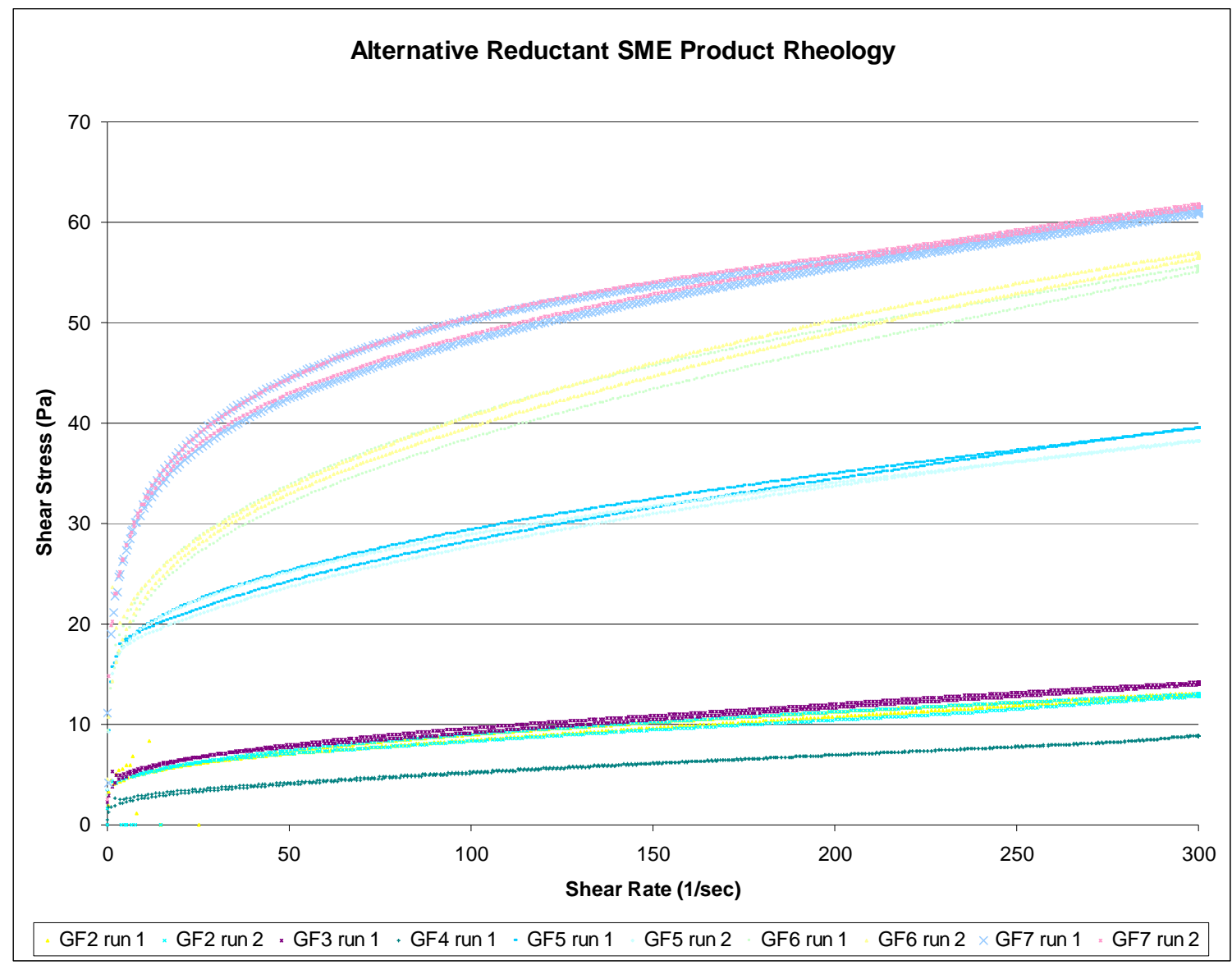




\section{A.3 SRAT Product Elemental Data}

\begin{tabular}{|l|c|c|c|c|c|c|c|c|}
\hline $\begin{array}{l}\text { elemental } \\
\text { wt\% SRAT } \\
\text { Product }\end{array}$ & GF1 & GF2 & GF3 & GF4 & GF5 & GF6 & GF7 & GF8 \\
\hline Al & 16.5 & 16.3 & 16.1 & 14.2 & 16.4 & 16.3 & 16.7 & 16.6 \\
\hline B & $<0.100$ & 0.1 & $<0.100$ & $<0.100$ & $<0.100$ & $<0.100$ & $<0.100$ & $<0.100$ \\
\hline Ba & 0.07 & 0.04 & 0.05 & 0.08 & 0.04 & 0.04 & 0.04 & 0.04 \\
\hline Ca & 0.60 & 0.53 & 0.54 & 0.66 & 0.57 & 0.59 & 0.57 & 0.56 \\
\hline Cd & 0.08 & 0.04 & 0.04 & 0.03 & $<0.010$ & $<0.010$ & $<0.010$ & $<0.010$ \\
\hline Ce & $<0.010$ & $<0.010$ & $<0.010$ & $<0.010$ & $<0.010$ & $<0.010$ & $<0.010$ & $<0.010$ \\
\hline Cr & 0.12 & 0.12 & 0.12 & 0.11 & 0.13 & 0.13 & 0.13 & 0.16 \\
\hline Cu & 0.23 & 0.25 & 0.23 & 0.19 & 0.25 & 0.16 & 0.27 & 0.26 \\
\hline Fe & 19.2 & 19.3 & 19.2 & 17.1 & 18.6 & 18.4 & 18.7 & 18.7 \\
\hline K & 0.04 & 0.17 & 0.03 & 0.03 & 0.03 & 0.03 & 0.06 & 0.03 \\
\hline La & $<0.010$ & $<0.010$ & $<0.010$ & $<0.010$ & $<0.010$ & $<0.010$ & $<0.010$ & $<0.010$ \\
\hline Li & $<0.100$ & 0.06 & $<0.100$ & $<0.100$ & $<0.100$ & $<0.100$ & $<0.100$ & $<0.100$ \\
\hline Mg & 0.46 & 0.46 & 0.46 & 0.50 & 0.47 & 0.47 & 0.48 & 0.48 \\
\hline Mn & 6.44 & 6.29 & 6.48 & 5.39 & 6.29 & 6.47 & 6.34 & 6.39 \\
\hline Mo & $<0.010$ & $<0.010$ & $<0.010$ & $<0.010$ & $<0.010$ & $<0.010$ & $<0.010$ & $<0.010$ \\
\hline Na & 15.55 & 15.45 & 15.60 & 16.45 & 15.69 & 16.44 & 16.03 & 15.99 \\
\hline Ni & 2.68 & 2.70 & 2.69 & 2.16 & 2.63 & 2.65 & 2.66 & 2.68 \\
\hline P & $<0.010$ & $<0.010$ & $<0.010$ & $<0.010$ & $<0.010$ & $<0.010$ & $<0.010$ & $<0.010$ \\
\hline S & 0.43 & 0.46 & 0.48 & 0.53 & 0.46 & 0.47 & 0.46 & 0.42 \\
\hline Si & 0.22 & 0.17 & 0.16 & 0.32 & 0.20 & 0.16 & 0.21 & 0.23 \\
\hline Sr & 0.03 & 0.03 & 0.03 & 0.02 & 0.08 & 0.08 & 0.08 & 0.08 \\
\hline Ti & 0.02 & 0.02 & 0.02 & 3.13 & 0.01 & 0.01 & 0.01 & 0.01 \\
\hline Zn & $<0.010$ & $<0.010$ & $<0.010$ & $<0.010$ & 0.01 & 0.01 & 0.01 & $<0.010$ \\
\hline Zr & 0.25 & 0.24 & 0.24 & 0.23 & 0.26 & 0.25 & 0.26 & 0.23 \\
\hline & & & & & & & & \\
\hline
\end{tabular}


A.4 SME Product Elemental Data

\begin{tabular}{|l|l|l|l|l|l|l|l|}
\hline $\begin{array}{l}\text { elemental } \\
\text { wt\% SRAT } \\
\text { Product }\end{array}$ & GF1 & GF2 & GF3 & GF4 & GF5 & GF6 & GF7 \\
\hline Al & 6.17 & 6.02 & 5.87 & 5.13 & 6.03 & 5.71 & \\
\hline B & 1.44 & 1.52 & 1.45 & 1.48 & 1.26 & 1.22 & 1.20 \\
\hline Ba & 0.03 & 0.01 & 0.02 & 0.03 & $<0.010$ & $<0.010$ & $<0.010$ \\
\hline Ca & 0.15 & 0.17 & 0.16 & 0.23 & 0.23 & 0.24 & 0.24 \\
\hline Cd & 0.03 & $<0.010$ & $<0.010$ & $<0.010$ & $<0.010$ & $<0.010$ & $<0.010$ \\
\hline Ce & $<0.010$ & $<0.010$ & $<0.010$ & $<0.010$ & $<0.010$ & $<0.010$ & $<0.010$ \\
\hline Cr & 0.06 & 0.05 & 0.05 & 0.05 & 0.05 & 0.05 & 0.05 \\
\hline Cu & 0.11 & 0.09 & 0.09 & 0.09 & 0.07 & 0.05 & 0.15 \\
\hline Fe & 7.27 & 6.77 & 7.04 & 6.08 & 7.35 & 6.86 & 6.78 \\
\hline K & 0.06 & 0.12 & 0.05 & 0.05 & 0.06 & 0.05 & 0.10 \\
\hline La & $<0.010$ & $<0.010$ & $<0.010$ & $<0.010$ & $<0.010$ & $<0.010$ & $<0.010$ \\
\hline Li & 2.15 & 2.28 & 2.19 & 2.21 & 2.22 & 2.15 & 2.12 \\
\hline Mg & 0.19 & 0.19 & 0.18 & 0.20 & 0.20 & 0.20 & 0.20 \\
\hline Mn & 2.31 & 2.26 & 2.22 & 1.83 & 2.58 & 2.41 & 2.32 \\
\hline Mo & $<0.010$ & $<0.010$ & $<0.010$ & $<0.010$ & $<0.010$ & $<0.010$ & $<0.010$ \\
\hline Na & 9.71 & 9.78 & 9.37 & 10.15 & 9.39 & 9.53 & 9.69 \\
\hline Ni & 0.87 & 0.75 & 0.75 & 0.60 & 0.80 & 0.81 & 0.93 \\
\hline P & 0.02 & $<0.010$ & $<0.010$ & $<0.010$ & $<0.010$ & $<0.010$ & $<0.010$ \\
\hline S & 0.16 & 0.14 & 0.14 & 0.14 & 0.16 & 0.15 & 0.14 \\
\hline Si & 22.92 & 23.69 & 23.69 & 23.67 & 23.46 & 23.71 & 23.02 \\
\hline Sr & $<0.010$ & $<0.010$ & $<0.010$ & $<0.010$ & 0.03 & 0.03 & 0.04 \\
\hline Ti & 0.04 & 0.05 & 0.04 & 1.02 & 0.03 & 0.03 & 0.03 \\
\hline Zn & $<0.010$ & 0.01 & $<0.010$ & 0.01 & $<0.010$ & $<0.010$ & $<0.010$ \\
\hline Zr & 0.17 & 0.17 & 0.16 & 0.24 & 0.20 & 0.19 & 0.19 \\
\hline & & & & & & & \\
\hline & & & & & & \\
\hline
\end{tabular}




\section{A.5 Additional GC Data}
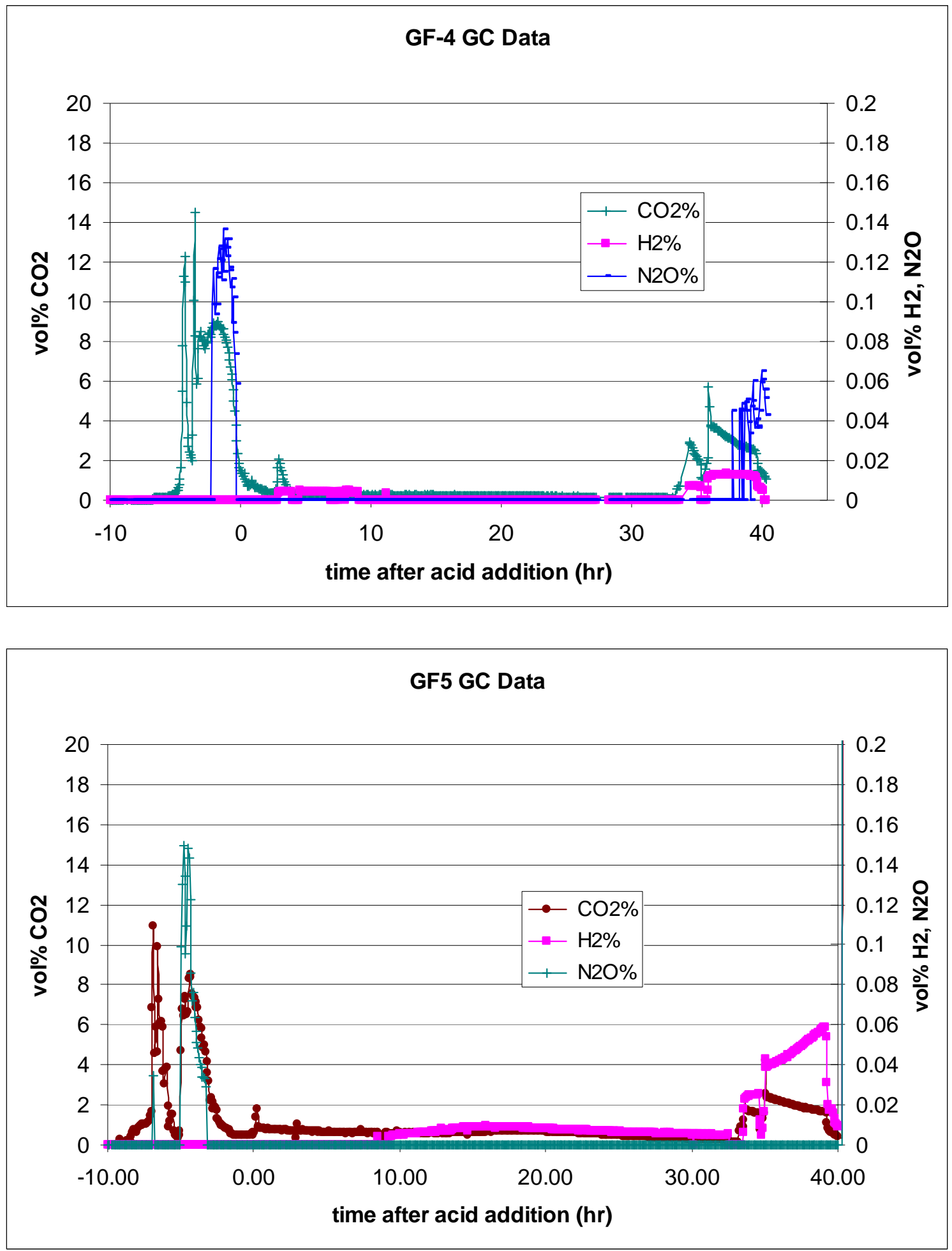

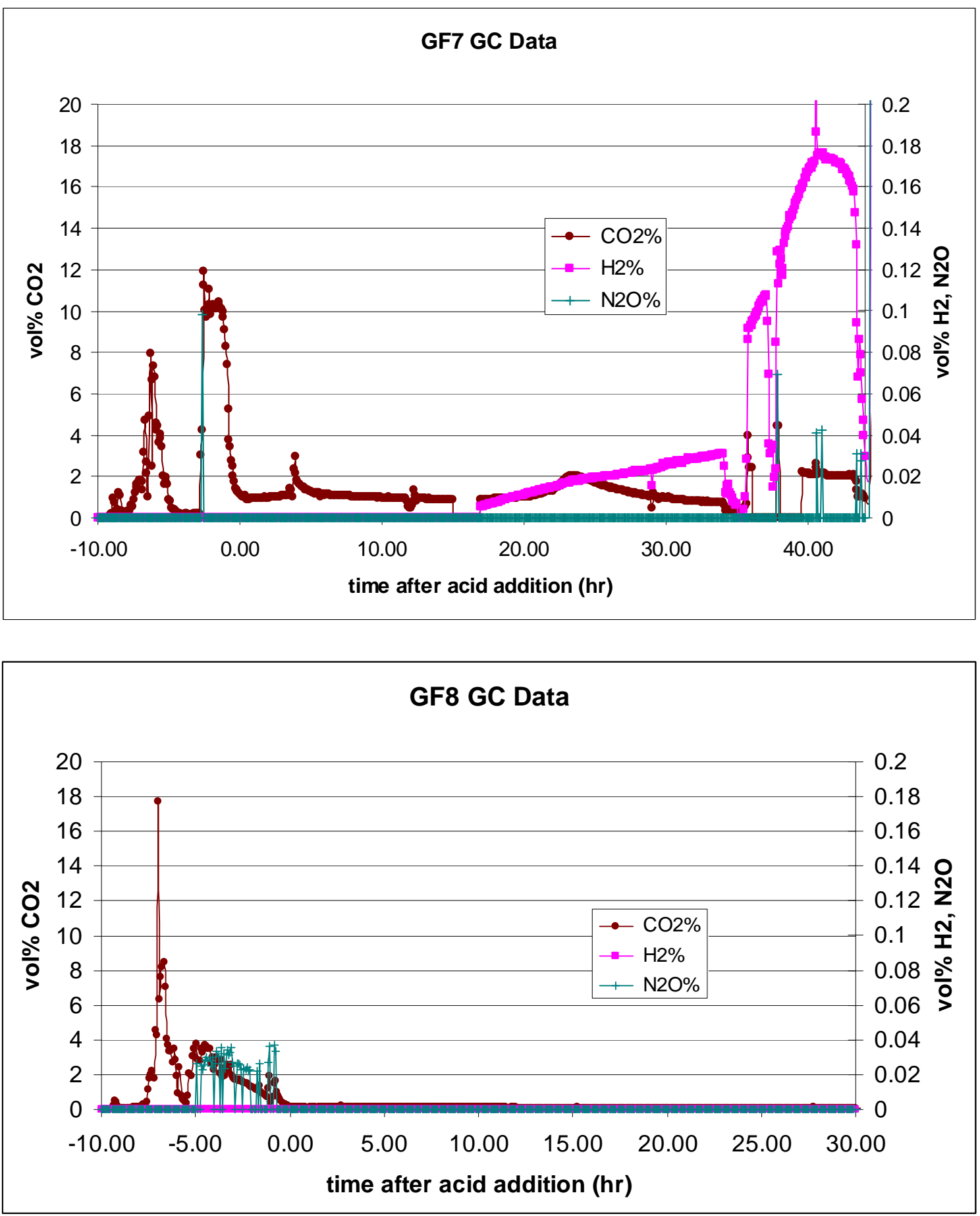


\section{Distribution:}
A. B. Barnes, 999-W
D. A. Crowley, 773-43A
S. D. Fink, 773-A
B. J. Giddings, 786-5A
C. C. Herman, 999-W
S. L. Marra, 773-A
F. M. Pennebaker, 773-42A
W. R. Wilmarth, 773-A
C. J. Bannochie, 773-42A
J. M. Gillam, 766-H
B. A. Hamm, 766-H
J. F. Iaukea, 704-30S
J. E. Occhipinti, 704-S
D. K. Peeler, 999-W
J. W. Ray, 704-S
H. B. Shah, 766-H
D. C. Sherburne, 704-S
M. E. Stone, $999-\mathrm{W}$
M. A. Broome, 704-29S
R. N. Hinds, 704-S
J. P. Vaughan, 773-41A
J. M. Bricker, 704-27S
T. L. Fellinger, 704-26S
E. W. Holtzscheiter, 704-15S
A. V. Staub, 704-27S
K. R. Shah, 704-S
M. T. Keefer, 766-H
D. P. Lambert, 999-W
D. C. Koopman, 999-W
A. I. Fernandex, 999-W
J. D. Newell, 999-W
D. R. Best, 999-W
R. E. Eibling, 999-W
W. T. Riley, 999-W 